\title{
Andriej Moskwin
}

Uniwersytet Warszawski

https://orcid.org/0000-0003-1699-3556

\section{Powieść dokumentalna Franciszka Alachnowicza „7 lat w szponach GPU": geneza utworu, cztery wersje}

Przedmiotem niniejszego artykułu jest analiza dokumentalnej powieści znanego białoruskiego literata i publicysty Franciszka Alachnowicz „7 lat w szponach GPU". Została ona napisana w krótkim czasie, tuż po wyjściu pisarza z obozu koncentracyjnego na Wyspach Sołowieckich oraz otrzymaniu możliwości powrotu do Wilna we wrześniu 1933 roku. Mimo trudnej sytuacji finansowej Alachnowicz natychmiast przystąpił do pisania wspomnień. Po dwóch latach, w 1935 roku, ukazały się one drukiem w języku polskim w Wilnie ${ }^{1}$. Utwór ten jest jednym z pierwszych i bardzo ważnych świadectw o początkach powstania w ZSRR obozów koncentracyjnych oraz opisu panujących tam porządków.

W 1937 roku powieść została opublikowana w Warszawie pod innym tytułem - „Prawda o Sowietach”. W latach 1935-1939 została przetłumaczona na siedem języków i opublikowana w Europie, Ameryce Łacińskiej oraz Stanach Zjednoczonych. W Brazylii publikacja ta miała tytuł polskiego oryginału ${ }^{2}$, we Włoszech zaś jej tytuł został zmieniony na inny: „Prawda o bolszewickiej Rosji" ${ }^{3}$. W języku białoruskim książka ujrzała światło dzienne w 1937 roku pt. „У капцюрох ГПУ” („W szponach GPU”, Wilno) ${ }^{4}$ w tłu-

\footnotetext{
1 F. Olechnowicz, 7 lat w szponach GPU, Wilno 1935.

2 F. Olechnowicz, Sete annos nas garras Sovieticas, São Paulo 1937.

3 F. Olechnowicz, La Verità sulla Russia Bolscevica. Casa editrice G. Nerbini, Firenze 1938.

4 Ф. Аляхновіч, У капиюрох ГПУ. Друкарня І. Баеўскага, Вільня 1937.
} 
maczeniu autora. Z czasem autor uzupełnił białoruską wersję i opublikował ją w dzienniku „Мінская Праўда” 5 .

Po drugiej wojnie światowej powieść ta ukazała się czterokrotnie. W 1991 roku miesięcznik „Полымя” (nr 1)6 zamieścił ją na swoich kartkach, korzystając z wersji z 1937 roku. Z kolei mińskie wydawnictwo „Maстацкая літаратура” („Literatura Piękna”) sięgnęło po drugą, znacznie poszerzoną wersję z 1942 roku. „У капцюрох ГПУ” ukazała się drukiem w $1994 \mathrm{roku}^{7}$, a towarzyszyły jej inne artykuły, m.in. wstęp autorstwa historyka literatury Alesia Bielackiego oraz krótki komentarz Aleha Dyszlewicza. W 2005 roku tekst ten został zamieszczony w „Dziełach wybranych” („Выбраныя творы") pisarza wraz z innymi utworami, m.in. pięcioma dramatami, wierszami, publicystyką oraz pracą teoretyczną „Беларускі тэатр” („Teatr białoruski”). Książka ukazała się w renomowanej serii „Беларускі Кнігазбор” („Księgozbiór Białoruski”). Czwarte z kolei wydanie ujrzało światło dzienne w 2015 roku w nowo powstałej serii „Мая беларуская кніга” („Moja Białoruska Książka”) ${ }^{9}$. W dwóch ostatnich wydaniach została wykorzystana ostatnia wersja powieści.

Celem niniejszego artykułu jest, po pierwsze, porównanie czterech wersji powieści - dwóch polskich (1935 i 1937 roku) i dwóch białoruskich (1937 i $1942 \mathrm{roku}) \mathrm{i}$, po drugie, prześledzenie, jak zmieniała się koncepcja autora w miare powstania nowych wersji.

Utwór ten był już przedmiotem badań polskich (Katarzyna Drozd i Anna Sakowicz ${ }^{10}$ ) i białoruskich badaczek (Alena Żdanowicz i Tacciana Baharadawa $\left.{ }^{11}\right)$. Jednak badaczki te, po pierwsze, skupiały się wyłącznie na bia-

5 Ф. Аляхновіч, У капцюрох ГПУ, „Мінская праўда”, 1941 - nr 7-12, 14-17, 19; 1942 - nr 1, 2, 4, 6, 7, 9-12, 14, 15, 17, 18, 21, 22, 24, 25, 29, 31, 32, 36, 37, 39, 41.

6 Ф. Аляхновіч, У капиюрох ГПУ, „Полымя” 1991, № 1, с. 151-214.

7 Ф. Аляхновіч, У капцюрох ГПУ, Мінск 1994.

8 Ф. Аляхновіч, У капиюрох ГПУ, [w:] Ф. Аляхновіч, Выбраныля творы, Mińsk 2005, с. 223-390.

9 Ф. Аляхновіч, У капиюрох ГПУ, Мінск 2015.

10 K. Drozd, „W szponach GPU” - o największym wrogu ludzkości, cz. 1. „Acta Albaruthenica", t. 8, Warszawa 2008, s. 62-71; K. Drozd, "W szponach GPU”-o największym wrogu ludzkości”, cz. 2. „Acta Albaruthenica”, t. 9, Warszawa 2009, s. 67-81; K. Drozd, Białoruska proza tagrowa, Warszawa 2016; А. Саковіч, Пакутнікі за народ i Бацькаўшчьну. (Мемуары Франиішка Аляхновіча і Янкі Жамойчіна), [w:] Białoruś: przeszłość i teraźniejszość: kultura, literatura, język (red. R. Radzik, M. Sajewicz), Lublin 2010, s. $123-133$.

11 А. Ждановіч, Сэнсаўтваральныя асаблівасці „У капиюрох ГПУ” Ф. Аляхновіча $i$ „Aповесчі для сябе” Б. Мікуліча ў кантэксце жанрава-стылёвых прыкмет гэтых творай, [ӱ] Куляшоўскія чытанні: матэрыяль Міжнароднай навукова-практычнай канферэнцыі, у 2 ч. (рэд. Л. Кілевая і інш.). Ч. 1. Магілёў 2010, с. 332-339; Т. Ба- 
łoruskiej wersji opowieści, a po drugie, miały nieco inny cel. K. Drozd rozpatrywała opowieść F. Alachnowicza w kontekście innych utworów o podobnej problematyce: „Spowiedź” („Споведзь”, 1990) Łarysy Geniusz, „Зона маўчання” ( „Zona milczenia”, 1996) Siarhieja Hrachouskiego i „Chiny-Sybir-Moskwa” ( „Кітай-Сібір-Масква”, 1962) Józefa Hermanowicza. Z kolei A. Sakowicz przeprowadziła paralele pomiędzy opowieścią Alachnowicza a wspomnieniami „Z tego, co przeżyłem” („3 перажытага”) Janki Żamojcina, a A. Żdanowicz - „Opowieścią dla siebie” ( „Аповесць для сябе”, 1948) Barysa Mikulicza. Z kolei badaczka z Połocka T. Baharadawa skupiła się na pokazaniu miejsca „У капцюрох ГПУ” („W szponach GPU”) w twórczości pisarza. Warto tu wspomnieć o publikacji polskiego historyka z Kanady Zenowiusza Ponarskiego „Franciszek Olecznowicz - wydawca, redaktor, publicysta" ${ }^{12}$, w której badacz przytacza kilka faktów związanych z losem badanej powieści.

W białoruskim literaturoznawstwie panuje przekonanie, że Alachnowicz po raz pierwszy odstonit dla catego cywilizowanego świata żelazna kurtyne $i$ pokazat w całym swym ,pięknie, że socjalizm jest niewolnictwem ${ }^{13}$. Pisano, że „7 lat w szponach GPU” jest pierwszym świadectwem o dzikiej komunistycznej furii na Białorusi, pierwsze wspomnienia czlowieka, który cudem wydostał się z radzieckiego piekta i pokazał całemu światu prawdziwe oblicze komunizmu ${ }^{14}$.

Należy jednak zaznaczyć, że nie była to pierwsza publikacja o funkcjonującym na Wyspach Sołowieckich obozie koncentracyjnym. Nieco wcześniej zostały opublikowane dwie inne opowieści autorstwa Sozierki Malsagowa („Piekielna wyspa. Radzieckie więzienie na dalekiej Północy”)15 oraz Jurija Biessonowa ( DDwadzieścia sześć więzień i ucieczka z Sołomków”) ${ }^{16}$. Autorami obydwu publikacji byli więźniowie Wysp Sołowieckich, którzy odważyli się w 1925 roku podjąć próbę ucieczki. Zakończyła się ona powodzeniem. Po przekroczeniu radziecko-fińskiej granicy ich drogi się rozeszły:

гарадава, Нетрадыцыйнасць праблематыкі аповесиі Ф. Аляхновіча „У капиюрох ГПУ”, „Вестник Полоцкого государственного университета: научно-теоретический журнал", Полоцк 2016, № 2, с. 72-76.

12 Z. Ponarski, Franciszek Olechnowicz - wydawca, redactor, publicysta, „Białoruskie Zeszyty Historyczne" 1996, z. 2 (6), s. 51-64.

13 А. Змітровіч, У капцюрох ГПУ, „Полымя” 1991, № 1, с. 150.

14 А. Бяляцкі, „Бо лёс бызу наш - мук дойгі, вечнь илях...”, [w:] Ф. Аляхновіч, У капчюрох ГПУ, Мінск 1994, с. 9.

15 S. Malsagoff, An Island Hell: A Soviet Prison in the Far North (translated by Francis Hamilton Lyon), London 1926, 223 pp.

16 Y. Bezsonov, Mes vingt-six prisons et mon évasion de Solovki (traduit du E. Semenoff), Paris 1928, 288 pp. 
Malsagow wyjechał do Wielkiej Brytanii, Biessonow zaś do Francji, gdzie w 1926 roku został zaproszony do parlamentu, aby opowiedzieć o własnych doświadczeniach. Obydwie publikacje najpierw zostały napisane w języku rosyjskim, a później przetłumaczone na inne języki - odpowiednio na angielski i francuski. Opowieść S. Malsagowa, zanim ukazała się w londyńskim wydawnictwie dzięki staraniom rosyjskiego dyplomaty Konstantyna Nabokowa i poety Iwana Sawina, ujrzała światło dzienne w wersji rosyjskiej na łamach rosyjskojęzycznej gazety „Сегодня” („Dziś”) w Rydze rok wcześniej - w 1925 roku pod innym tytułem: „Wyspy Sołowieckie - miejsce tortur i śmierci". W 1927 roku we Francji wyszło drukiem świadectwo Raymonda Dugneta „Więzienie w Czerwonej Rosji” (1927)17.

W latach 30. XX wieku czytelnik europejski mógł się zapoznać z nowymi świadectwami: „Ucieczka od Sowietów” (1933) Tatiany Czernawiny ${ }^{18}$, „Ja mówię w imieniu milczących więźniów kraju Rad” (1935) Władimira Czernawina ${ }^{19}$, „Czerwone więzienie. Wspomnienia o łagrach w kraju Sowietów” (1935) Julii Danzas ${ }^{20}$ oraz „Rosja w obozie koncentracyjnym” (1935) Iwana Sołoniewicza ${ }^{21}$.

\section{Wydanie w języku polskim: „,7 lat w szponach GPU” (1935)}

Wydana w 1935 roku powieść składa się z sześciu części: I - Mińsk, II - Wyspa Popowska, III - Wyspa Miah, IV - Sołowki, V - Kiem i VI - Moskwa. Każda część zawiera rozdziały:

I - piętnaście (Cela w piwnicy, Mój towarzysz, Na Komarówkę!, Judaszowska robota, Apanasik, Nowy „legawy”, Karcer, Straszna improwizacja,

17 R. Dugnet, Un bagne en Russie rouge, Paris 1927.

18 T. Tchernavin, Escape from the Soviets, London 1933.

19 V. Tchernavin, I speak for the silent prisoners of the Soviets, Boston - New York 1935 .

20 [Iulia Danzas], Bagne rouge. Souvenirs d'une prisonnière au pays des Soviets. Les Éd. du Cerf - Istina, Centre dominicain d'études russes, Juvizy 1935. J. Danzas przebywała na Wyspach Sołowieckich od września 1928 roku do stycznia 1931. W styczniu 1932 roku została zwolniona przedterminowo i dzięki pomocy M. Gorkiego emigrowała - najpierw do Berlina, a później do Francji i Włoch. Podczas spotkania pisarz powiedział jej: „Tylko proszę, aby pani o swoim pobycie na Wyspach Sołowieckich nic nie pisała i z nikim o tym nie rozmawiała...". Jednak historyczka i teolożka nie dotrzymała słowa.

21 И. Солоневич, Россия в конилагере, газета „Последние Новости” (Париж), 1935. Począwszy od 20 I 1935 gazeta zamieściła 118 esejów. W wersji książkowej teksty te ukazały się w 1936 roku w Bułgarii. Wkrótce przetłumaczono je na język niemiecki i wydano w 1937 roku: Iwan Solonewitsch, Die Verlorenen. Eine Chronik namenlosen Leidens. Rußland im Zwangsarbeitslager 1933, Essen 1937. 
Bóg chciat, Egzekucje, „Inscenizacje”, Psychoza, „Wojkowcy”, Katastrofa pod Minskiem, Etapem);

II - osiem (Przybycie do obozu, W baraku, Na robotę!, Eaźnia, Dalsza podróż, Sioła karelskie, „Miecz rewolucji”, Śpiew żabi);

III - siedem (Na robocie, Ponad sity, „Samoruby”, Strajk, Wikt, Niefortunna ucieczka, Odjazd na Sołowki);

IV - trzydzieści trzy (Nowe warunki życia, Zmniejszenie kary, Seksoci, Kobieta na Sołowkach, Cmentarz, ISO, Izolator, W obliczu śmierci, Wyspa Kond, Siekierka, Żordoczka, Złudne nadzieje, Humor kazamatów, Epidemia tyfusu, Komisja z Moskwy, Zmiany, Zima, Pomory, Listy, Marzenia i koszmary, Czytanie rozkazu, Wiosna, Sprawy religijne, „Wychowanie” więźnia, Teatr, Wizyta Gorkiego, Kino, Biblioteka, Muzeum, Sport, Podziat więźniów, Nadzy... w grudniu!, Kradzieże);

V - cztery (Na Wegierakszy, Gazeta $i$ radio, $W$ izolatorze, $W$ drodze);

VI - siedem (Butyrki, Za późne żale, „Konwejer”, Towarzysze z Sołówek, Niespodzianki, Ku granicy, Wymiana).

Jedne rozdziały mają objętość jednego-trzech akapitów, a drugie - kilku stron. Tytuły najczęściej są konkretne i noszą informacyjny charakter. Alachnowicz miał na celu przede wszystkim opisać przebieg swojego aresztowania i pobyt w łagrze; pokazać codzienne życie łagrowe i panujące w nim zasady; odsłonić prawdziwe oblicze systemu socjalistycznego, który kusi człowieka, proponuje mu włączyć się w proces budownictwa, a następnie go oskarża o zdradę i likwiduje albo skazuje na dziesięć lat niewoli (jak w przypadku Alachnowicza); ostrzec przed niebezpieczeństwem ze strony radzieckiej władzy i zagrożeniem totalitaryzmu, które lada chwila ma przyjść.

Opowieść zaczyna się w dniu 2 stycznia 1927 roku, gdy Alachnowicz zostaje aresztowany podczas podróży pociągiem z Witebska do Mińska, a kończy się 6 września 1933 roku, gdy został zwolniony z łagru w drodze wymiany politycznej - wymieniono go na Branisława Taraszkiewicza22. Literat otrzymał wtedy możliwość powrotu do Polski. W rezultacie Alachnowicz spędził w niewoli sześć lat, osiem miesięcy i cztery dni. Czas ten został przez niego dokładnie opisany.

22 Branisłau Taraszkiewicz (1892-1938) - białoruski polityk, poseł na Sejm Rzeczypospolitej, przewodniczący Białoruskiego Koła Poselskiego, przywódca Białoruskiej Włościańsko-Robotniczej Hromady, działacz społeczny, językoznawca, tłumacz, jeden z twórców gramatyki języka białoruskiego. W 1928 Bronisława Taraszkiewicza za działalność komunistyczną skazano na 12 lat więzienia. Zwolniony z więzienia w 1930 roku, po wyjściu na wolność mieszkał w Gdańsku. 5 II 1931 został ponownie aresztowany przez władze polskie, próbując przejechać przez terytorium Polski z Gdańska do Berlina, a w listopadzie 1932 roku skazany na 8 lat więzienia. W 1933 r. zgodził się na wyjazd do ZSRR i 3 IX 1933 został wymieniony na F. Alachnowicza. 
Tuż po areszcie autor przebywał w dwóch mińskich więzieniach. Jak tylko na początku grudnia 1927 roku zapadła decyzja o skazaniu na dziesięć lat więzienia, miał jechać na Wyspy Sołowieckie. Droga prowadziła go przez Orszę (spędził tam dwa tygodnie), Witebsk (spędził około miesiąca) i Leningrad (spędził kilka godzin). Po trzech dniach jazdy pociągiem dotarł na Wyspę Popowską ${ }^{23}$ w pobliżu Kiemi ${ }^{24}$, gdzie przez dwa tygodnie odbył kwarantannę. Następnie wraz z grupą więźniów został odwieziony pociągiem do stacji Soroka ${ }^{25}$. Stamtąd na piechotę doszedł do wsi Koleżma ${ }^{26}$, a potem $20 \mathrm{~km}$ na wyspę $\mathrm{Miah}^{27}$. Tam przebywał od lutego do 29 maja 1928 roku, po czym został odwieziony statkiem "Newa” na Wyspy Sołowieckie. Pobyt na Sołowkach trwał od końca maja 1928 roku do jesieni 1932 roku (dokładna data nie została podana). Następnie Alachnowicz zostaje odwieziony do miasta Kiem, gdzie przebywa do 15 lipca 1933 roku. Od 17 lipca znajduje się w Moskwie w więzieniu na Butyrkach ${ }^{28}$, a w dniu 4 września zostaje wywieziony do Mińska.

Po tym, jak 2 stycznia 1927 roku, Alachnowicz został aresztowany, trafił do jednego z mińskich więzień. Jego pierwsza cela to mały zimny pokój w piwnicy z wybitymi szybami. Po dwóch dniach został przeniesiony do innej, znacznie lepszej celi. Miał do swojej dyspozycji stół i dwa taborety, a co najważniejsze - było w niej ciepło.

23 Wyspa Popowska (Попов Остров, оbecnie Рабочеостровск/Raboczeostrowsk) - wieś w Republice Karelia. Znajduje się na odległości $12 \mathrm{~km}$ od miast Kiem na wybrzeżu Białego Morza. Została założona w 1888 roku przez kupców z Archangielska i otrzymała nazwę Wyspa Popowska. Miejsce to zostało wybrane nieprzypadkowo: jest wygodne dla statków. Według wstępnych planów pracownicy mieli tam przyjeżdżać wyłącznie w okresie letnim. Jednak z czasem część z nich zostawała i w rezultacie powstała wieś. W latach 1918-1924 wieś miała nazwę Красный Остров (Wyspa Czerwona), 1924-1929 - Ocтров Октябрской Революции (Wyspa Rewolucji Październikowej), a od 1929 - Raboczeostrowsk. W 1923 roku otwarto tu punkt dla zesłańców, których kierowano na Wyspy Sołowieckie.

24 Kiem (w języku karelskim - Wegeraksza, czyli gniazdo wiedźm) - miasto w składzie Republiki Karelii. Osady w okolicach dzisiejszego miasta powstały w XIV wieku, nie wiadomo jednak dokładnie, która z nich stała się podstawą dla Kiemi. Na pewno Kiem w miejscu obecnej lokalizacji znajdował się w XV w. W początkowym okresie istnienia osada była kilkakrotnie zdobywana i niszczona przez Szwedów. Prawa miejskie uzyskała w 1785 roku. W 1926 roku mieszkało tam 12 tysięcy osób. Mieściła się tam administracja obozu Sołowieckiego oraz punkt przeładunkowy skazańców.

25 Soroka - wieś w Republice Karelii, leży na brzegu Morza Białego. Po raz pierwszy została wspomniana w latopisach z 1419 roku. Powstały tam liczne tartaki.

26 Koleżma - wieś, powstała w XVI wieku. Główne zajęcie mieszkańców - łowienie ryb. W 1926 roku mieszkało tu 1168 osób.

27 Miah (Остров Мягостров) - wyspa w Zatoce Oneskiej Morza Białego.

28 Butyrki - więzienie przejściowe i śledcze w Moskwie, służące także do przetrzymywania więźniów politycznych. Drugie obok Łubianki znane moskiewskie miejsce kaźni w okresie stalinowskim. 
Jak wynika z powieści, autor chętnie poznawał inne osoby, z którymi lubił rozmawiać, uzyskując w ten sposób informacje o przyczynach aresztowań. Wiedział, że od czasu do czasu odbywały się sądy: jednych skazywano na karę śmierci, inni zaś otrzymywali terminy (przeważnie 10 lat). Alachnowicz zaś przez dłuższy czas przybywał w niewiedzy: Nawał myśli kotłowat sie w mej głowie, nie mogłem jeszcze zrozumieć swojego położenia, za co, w jakim celu zostatem zaaresztowany, wtedy bowiem nie zrodziło mi sie jeszcze $w$ głowie przypuszczenie, że zostałem sprowadzony do ZSRR prowokacyjnie ${ }^{29}$.

Stopniowo w świadomości Alachnowicza zaczął się kształtować obraz tego, jak funkcjonuje GPU i jakie środki stosuje się dla osiągnięcia celu. Dowiedział się także, że wyrok sądu nie obowiązuje GPU i zdarza się, że wysyłka do Gułagu może zostać zastąpiona rozstrzelaniem. Odbywało się to w poniedziałek, tuż po tym, jak kurier dostarczał z Moskwy decyzje. Osądzonych na śmierć wsadzano do auta i odwożono do lasu Komarowskiego ${ }^{30}$. Początkowo egzekucje odbywały się rzadko, ale z czasem coraz częściej. Wprowadzało to wszystkich w straszny popłoch:

Odgłos silnika auta, stojacego w podwórzu, działat na wszystkich elektryzujaco. Śmiechy milkty, rozmowy się urywały, kłótnie cichty... W korytarzu stychać już odgłos zbliżających się kroków. Ida! Już!... Nie! Przeszli. Nasza cele ominęli. Gdzieś zgrzytną klucz w zamku. Wszyscy zamarli, jak pies na czatach. Nastuchuja (s. 19).

Od czasu do czasu organizowano „inscenizacje”: ofiarę wywożono do lasu, przystawiano do głowy lufę rewolweru i żądano, aby przyznała się do winy i udzieliła niezbędnych informacji. W zamian za to obiecano jej darować życie. Jednym z takich osób był młody chłopak Wołk-Michajłow, z którym Alachnowicz przebywał w jednej celi. Mimo, iż powiedział wszystko, czego od niego się domagano, to po dwóch miesiącach został rozstrzelany.

Niepewność, strach o własne życie, stan ciągłego napięcia - wszystko to bardzo negatywnie wpływało na zdrowie więźniów. Niektórzy z nich zaczęli mieć objawy psychozy. Coraz częściej w nocy było słychać jęki i krzyki, przyczyną których były pełne dramatyzmu sny. Jak wyznaje autor, tragedia ta nie ominęła i jego: po powrocie z łagru śniły mu się przesłuchania w zaściankach GPU, turkot przyjeżdżającego o zmroku auta i wywożącego do lasu Komarowskiego ofiary.

29 F. Alachnowicz, 7 lat w szponach GPU, Warszawa 1990, s. 5. Wszystkie przytoczone $\mathrm{w}$ tekście cytaty zostały przetłumaczone przez autora tekstu.

30 Las Komarowski - las, mieszczący się na obrzeżach Mińska. Obecnie - Park Kultury i Odpoczynku im. Czeluskina (został otwarty w 1932 roku). W latach 20. i 30. XX wieku rozstrzeliwano tu ludzi. 
Z czasem Alachnowicz przekonał się, że wśród więźniów są tacy, który wykonują „robotę Judasza” - robią sprawozdanie z rozmów i zachowań współwięźniów, a następnie informują o tym. Informatorzy od czasu do czasu wymieniają się i należało zachować ogromną ostrożność w kontaktach z nimi. W opowieści jest mowa o dwóch takich osobnikach. Jeden z nich to łotewski oficer, który został aresztowany przez pracowników GPU na pograniczu łotewsko-białoruskim. Podczas przesłuchania wydał wszystkich współpracowników, zamieszkałych w ZSRR. Drugi to starszy człowiek, skazany na 10 lat za szpiegostwo na rzecz Polski. Za przysługę obiecano mu wolność w ciągu trzech miesięcy. Miał lepsze wyżywienie, a od czasu do czasu otrzymywał nawet pieniądze na zakup dodatkowego jedzenia. Minęły jednak trzy miesiące, a w jego życiu nie zachodziły żadne zmiany.

Dla „nieposłusznych” osób, które łamały przepisy albo nie dawały wymaganych zeznań, istniał karcer. Było to małe, bardzo niskie, wilgotne i ciemne pomieszczenie pod schodami. Po paru dniach pobytu w takim pomieszczeniu więzień wyglądał, jakby przeszedł ciężką chorobę.

Alachnowicz był świadkiem wielu scen, które odbywały się w więzieniu. Jedna z nich wywarła na niego wielkie wrażenie. Kobieta została pozbawiona dzieci, a sama trafiła do karceru. Rozdzierajacy dusze krzyk rozlegat sie na korytarzu, gdy odrywano matke od dzieci. Dlugo było stychać szamotanie się, snadź kobieta stawiata opór. [...] Krzyk jednak trwat dalej (s. 16) - notuje autor. Nasunęły mu się skojarzenia ze zwyczajem lamentowania na pogrzebach, kiedy zawodowe płaczki lamentują nad zwłokami zmarłego: Coś podobnego ustyszatem teraz. Tylko że to nie był ów wyuczony szloch nad umartym, to byt prawdziwy krzyk rozpaczy, wyrywajacy sie z piersi nieszczesnej. To była jakaś straszna improwizacja kobiety z ludu w chwili największego nerwowego napięcia, wyrażajacej swe bóle skandowanymi tyradami (s. 17)

Jak podkreśla Alachnowicz, nigdy nie można było przewidzieć, ilu więźniów będzie w celi. Czasem było niewielu i wtedy każdy miał swoją własną pryczę. Ale zdarzały się okresy, kiedy więzienie było przeludnione: na jednej pryczy spało kilka osób, jeden przy drugim, brakowało powietrza. Autor przytacza dwa wydarzenia, które spowodowały liczne areszty. Jedno miało miejsce w Warszawie 7 czerwca 1927 roku, gdy rosyjski monarchista Borys Kowerda ${ }^{31}$ zastrzelił sowieckiego posła Piotra Wojkowa. Władza radziecka postanowiła wykorzystać tę sytuację dla walki z przeciwnikami i wrogami ustroju socjalistycznego. W rezultacie ten, który posiadal jakąkolwiek wła-

31 Borys Kowerda (1907-1987) - rosyjski działacz emigracyjny pochodzenia białoruskiego. Przygotował i zrealizował zamach na przedstawiciela dyplomatycznego (posła) ZSRR w Polsce Piotra Wojkowa. Miało to miejsce w Warszawie na Dworcu Głównym (7 VI 1927). 
sność, pracował jako urzędnik w carskiej administracji, nie chciał włączyć się w proces budowania socjalizmu, albo wyraził jakiekolwiek niezadowolenie z sukcesów Kraju Rad - mógł zostać aresztowany i skazany na kilkuletnie więzienie. Te wszystkie osoby nazywano „wojkowcami”: Wyraz ten tłumaczyt wszystko. To znaczy, że winy w danym wypadku doszukiwać sie próżno, $\dot{z}$ e został aresztowany $w$ okresie terroru, rozszalatego po zabójstwie petnomocnika sowieckiego, i dziś pokutuje w kazamatach jako „wspótwinowajca” Kowerdy (s. 25).

Druga sytuacja to wypadek na trasie pomiędzy przygraniczną stacją Stołpce a Mińskiem, w rezultacie którego zginął przewodniczący mińskiego GPU Józef Opański ${ }^{32}$, a naczelnik jednego z oddziałów GPU Korytow został ciężko ranny. Wieziony przez nich polski szpieg uciekł. Prasa interpretowała to wydarzenie jako działanie zamachowców, jednak po mieście krążyły pogłoski, że przyczyną katastrofy była zbyt szybka jazda. W wyniku przeprowadzonej przez GPU akcji zostało aresztowanych wiele niewinnych osób.

Po otrzymaniu wyroku - wysłanie do obozu na Wyspy Sołowieckie na 10 lat - Alachnowicz został przeniesiony do innego więzienia, gdzie spędził dwa tygodnie. Tam po raz pierwszy spotkał się z elementami kryminalnymi. Jak zaznacza, obcowanie z nimi było bardzo uciążliwe i nawet niebezpieczne: czuli się oni gospodarzami, okradali innych w dzień i noc, grozili zabójstwem, wywoływali konflikty i napięcia. Skarga do administracji nie tylko nie pomagała, lecz przeciwnie - powodowała nowe konflikty i chęć dokonania zemsty.

Druga część powieści została poświęcona pobytowi na Wyspie Popowskiej, znajdującej się w odległości dziesięciu kilometrów od Kiemi i połączonej z lądem tamą. Miejsce pobytu - barak, w którym brakowało miejsca. Na jednej pryczy mogło przebywać kilka osób. Szczególnie uciążliwe było to w nocy: nikt nie mógł się poruszyć, a obrócenie się na drugą stronę było możliwe po porozumieniu się z najbliższymi sąsiadami. Ponieważ na wyspie nie było wody, należało ją przywieźć z miasta. Zdarzało się, że za czajnik dodatkowego wrzątku trzeba było zapłacić nawet kilka rubli.

Od razu wszyscy zostali zaprowadzeni do łaźni, gdzie każdy otrzymał po kawałku mydła i po dwa małe pojemniki: jeden - z morską wodą, drugi z rzeczną. Ci, którzy nie wiedzieli o deficycie wody, mieli trudności ze zmyciem z siebie mydła. Następnie odbywały się badania lekarskie pod kątem zdolności do pracy fizycznej i w celu otrzymania odpowiedniej kategorii.

32 Józef Opański (1897-1927) - radziecki działacz partyjny. Od 1924 roku zastępca przewodniczącego GPU BSRR. Zginął 7 VI 1927 w wypadku samochodowym, jednak oficjalna wersja jest inna: został zabity przez „wrogów rewolucji podczas akcji terrorystycznej”. 
Po dwóch tygodniach kolejna podróż: najpierw pociągiem, a następnie pieszo. Zdarzało się, że w ciągu jednego dnia trzeba było przejść wiele kilometrów, by dotrzeć do kolejnej wioski i móc przenocować w izbie karelskiej. Jak podkreśla Alachnowicz, nikt wówczas nie myślał o ucieczce: ofiara zostałaby dość szybko schwytana i przekazana w ręce władzy, ponieważ za jego głowę dawano dwa pudy białej pszennej mąki.

Bardzo ważne miejsce w powieści zajmuje rozdział Miecz Rewolucji. Tak nazywano OGPU - Główny Państwowy Urząd Polityczny (ОГПУ - Объединённое Государственное Политическое Управление). Informację o nim Alachnowicz uzyskał prawdopodobnie od swoich współtowarzyszy, którzy mieli nieszczęście tam trafić. Jak podkreśla autor, jest to olbrzymi gmach, Bastylia, „serce terroru sowieckiego”, które wznosi się w centrum Moskwy. Powszechnie znane jest jako Łubianka nr 2. Tu w dzień i w nocy praca wre bez przerwy: przywożą i odwożą ludzi. Więzień trafia do piwnicy, ale dość szybko zostaje wezwany na przesłuchanie. Prowadzony przez korytarz nie ma prawa do kontaktu z innym więźniem. W tym celu gepista (pracownik GPU) wykonuje ruch klaśnięcia palcami, co oznacza, że „droga jest wolna".

Jak podkreśla autor, w ZSRR obowiązuje zasada współzawodnictwa socjalistycznego („соревнование”) і przekroczenia normy pracy („ударничество"). Polega to na tym, że, po pierwsze, każdy robotnik powinien nie tylko wykonać wyznaczoną normę, lecz dążyć do tego, aby zrobić więcej. Po drugie, wejść we współzawodnictwo z innymi pracownikami. W rezultacie „wszyscy wszędzie pracują w jakimś szalonym galopie. To, że w owym wyścigu pracy cierpi jakość produkcji - nie ulega żadnej wątpliwości" (s. 36). W podobny sposób pracują gepiści: każdy stara się skazać na śmierć najwięcej osób: „Byle więcej, byle srożej, byle bezlitośniej” (s. 37).

Każdy, kto trafia w ręce OGPU, usiłuje odgadnąć: jaki los gotuje mu śledczy. Nie był wyjątkiem i Alachnowicz:

Dla mnie kolegium OGPU zgotowało los zesłania do obozu sołowieckiego na dziesięć lat, tzn. oderwanie mnie od życia na zawsze. Po odbyciu bowiem wymierzonej mi kary miałbym wędrować na wygnanie do tundry Pieczorskiej, lub do kraju Narymskiego i po kilku latach pobytu na wygnaniu w najlepszym razie - jeżeli tam nie umarłbym z głodu lub nie zostałbym ponownie aresztowany - pozwolono by mnie zmienić miejsce pobytu, przenosząc mnie do okręgów z nieco łagodniejszym klimatem, lecz do ojczyzny - na Białoruś - nie pozwolono mi wrócić nigdy. Nigdy! Nie usłyszę już klekotania bocianów nad strzechą, ani pieśni wracających z pola żniwiarzy, ani przecudnego śpiewu po zachodzie słońca żab białoruskich w naszych jeziorach... (s. 39) 
Trzecia część opowieści opisuje pobyt Alachnowicza na wyspie Miah. Zajmuje ona szczególne miejsce, ponieważ pokazuje w miniaturze, jak wygląda obóz i z czym ma zetknąć się więzień po przybyciu na Wyspy Sołowieckie. Jak zaznacza autor, jest to stosunkowo mała wyspa, licząca tylko dziesięć kilometrów. Znajdowało się tam sześć baraków oraz łaźnia, pralnia, suszarnia odzieży, stajnie i budynek mieszkalny administracji. Przebywały tu dwie kategorie więźniów: kryminaliści (zbóje, złodzieje, aferzyści) i kontrrewolucjoniści (nazywani w skrócie „kaerzy” - zamożni chłopi, inteligencja). Ci ostatni byli w mniejszości i stanowili tylko jedną czwartą. Nie byli lubiani przez kryminalistów, uważani za „najgorszy gatunek” i okrzyknięci „frajerami”.

Alachnowicz został ulokowany w jednym z ciemnych, zanieczyszczonych baraków. Wieczorem otrzymał swoje ubranie: watowane spodnie i kurtkę, czapkę, rękawice i walonki. Pierwszego dnia praca nie była zbyt trudna: należało utorować drogę dla sań, podążających do lasu po wyrąbane drzewo. Następnego dnia rozpoczęto pracę przy wyrębie drzew. Jak podaje autor, trwało to przez dwa miesiące: od końca lutego do końca kwietnia 1927 roku. Potem przez miesiąc więźniowie zbijali tratwy, które miały być holowane parowcem do Archangielska.

Przez kilka miesięcy pobytu w Miahu życie wyglądało w ten sam sposób. O trzeciej nad ranem - pobudka. Najpierw należało jak najszybciej odnaleźć swoje ubranie, które wymagało wysuszenia, a potem biec z miską po śniadanie. Jak stwierdza Alachnowicz, w tym okresie karmiono „stosunkowo nieźle": na śniadanie dawano miseczkę fasoli, soczewicy, grochu, kaszy gryczanej lub gęstej zupy z makaronami, na kolację - miskę barszczu lub jakiejśs zupy oraz kawałeczek gotowanego mięsa solonego, trochę większy od pudełka zapałek. Chleb - kilogram na osobę. Ponadto w kramie można było nabyć herbatę, cukier, konserwy, kiełbasę, śledzie, herbatniki, papierosy.

Gdy rozlegał się dzwon, wszyscy musieli stawić się na podwórku do apelu. Po tym, jak każdy otrzymywał narzędzie pracy - piłę, siekierę i łopatę, wyruszano do lasu. Tam wszyscy byli podzieleni na trójki. Więźniowie pierwszej kategorii (najbardziej doświadczeni i fizycznie wytrzymali) mieli zwalić 65 drzew, a drugiej - 45. Po ścięciu drzewa należało obrąbać gałęzie i złożyć je w kupę, a także wyciąć mniejsze drzewa i krzaki, aby sanie mogły przejechać.

Po zrobieniu normy można było wrócić do baraku - nawet o godzinie trzynastej. Z kolei inni musieli zostać i kontynuować robotę. Zdarzało się, że ostatnie trójki wracały do baraku około północy. Ci, którzy nie byli w stanie wykonać zadania, pozostawali na noc. Rano otrzymywali tylko zmniejszoną porcję chleba i kontynuowali robotę - wypełniając zadanie następnego dnia. 
W baraku przez dzień mieli prawo pozostać tylko „dniewalni” (niedołężni, inwalidzi) oraz chorzy. Pierwsi mieli obowiązek sprzątać, odnieść do suszarni przemoczone ubranie więźniów, palić w piecu. Z kolei drudzy otrzymywali zwolnienie z pracy na jeden dzień w przypadku zranienia czy przeziębienia (pod warunkiem, że temperatura wynosiła przynajmniej 38-39 stopni). Zbyt często z powodu wycieńczenia fizycznego, niezdolności do wykonania narzuconej z góry normy więźniowie byli doprowadzani do rozpaczy, popadali w depresję. Niektórzy nawet decydowali się na to, aby odciąć sobie palce albo lewą rękę. Alachnowicz wspomina, że pewnego razu jeden więzień podjął próbę ucieczki. Jednak po godzinie został odnaleziony i rozstrzelany. Następnego dnia ciało ofiary włożono do skrzyni i pogrzebano: Ani słowa współczucia, ani słowa powagi, jaka zwykła towarzyszyć odprowadzaniu człowieka na wieczny spoczynek. Drwiny, kpiny, wyzwiska, przekleństwa-jakby ten więzien grzebany nie byt towarzyszem niedawnym niewoli, lecz wrogiem najgorszym... (s. 57)

Wolny dzień przypadał dwa razy na miesiąc - co drugą niedzielę. Kiedy pewnego razu administracja obozu skasowała jeden dzień, więźniowie postanowili strajkować i następnego dnia odmówili wyjścia do pracy. Wtedy kierujący robotami starszy dziesiętnik kazał wszystkim wyruszyć do lasu, a po przejściu trzech kilometrów powiedział: ten, kto chce pracować, musi wziąć narzędzie, a ten, kto nie chce, ma się rozebrać. Więźniowie polityczni mieli obawę, że jeśli dołączą do kryminalistów, później zostaną oskarżeni o zainicjowanie strajku i rozstrzelani. Dlatego po krótkim wahaniu zgodzili się przystąpić do roboty, za co później otrzymali po 20 kopiejek. Z kolei wszyscy kryminaliści postanowili kontynuować strajk: Dziwna ironia losu, dziwne przewartościowanie walorów! Polityczni tamia strajk i pokornie ida do pracy, kryminaliści zaś mężnie obstaja przy swoim do ostatka! (s. 52)

Gdy pod koniec maja 1928 Alachnowicz wraz z grupką innych więźniów został odwieziony na Wyspy Sołowieckie, wierzył, że czekają tam na niego lepsze, „znośniejsze” warunki życia i pracy: Mówiono, że tam można otrzymać pracę wedtug swojej specjalności, że dzień roboczy jest tam normowany ilościa godzin pracy od 8 do 10 i o temu podobnych ulgach, do których wzdychaliśmy z tęsknota. [...] na statek taduje się kilkunastu katorżan z oczami błyszczacymi nadzieja. Nadzieja?! Czego? Jaka? Nadzieja wolności? - Nie! Tylko nadzieja znośniejszych, niż na Miahu, warunków życia... (s. 58)

Czwarta część opowieści, najbardziej obszerna, została poświęcona pobytowi Alachnowicza na Wyspach Sołowieckich. Jest to grupa wysp, położonych w Zatoce Oneskiej Morza Białego. Największe z nich to Wyspa Sołowiecka, Wyspa Anzerska, Wielka Wyspa Muksałma, Mała Wyspa Muksałma, Wielka Wyspa Zajęcza i Mała Wyspa Zajęcza. Ponadto w skład 
archipelagu wchodzi około 100 małych wysepek. Powierzchnia największej z wysp - Wyspy Sołowieckiej - $256 \mathrm{~km}^{2}$. Właśnie tu w latach 30. XV wieku powstał monastyr, będący w XV i XVI w. najważniejszym centrum kulturalnym i religijnym północnej Rosji. Po przewrocie bolszewickim w 1917 roku klasztor został zamknięty (1920) i zaczął służyć za obóz koncentracyjny OGPU - SŁON (Sołowiecki Obóz Specjalnego Przeznaczenia). Powstał w październiku 1923 roku decyzją Rady Komisarzy Ludowych ${ }^{33}$, w której zostało podkreślone: Jest to obóz przeznaczony dla izolacji szczególnie niebezpiecznych przestępców państwowych, zarówno kryminalnych, jak i politycznych, którzy nanieśli albo moga nanieść szkodę spokojnemu rozwojowi $i$ bezpieczeństwu ZSRR. Pod koniec tegoż roku skierowano tu ponad 3 tysiące więźniów. Z czasem ta liczba się zwiększała. Pod koniec kwietnia 1930 roku wynosiła ona 57 tysięcy osób, a w 1931 roku osiągnęła nawet 72 tysiące. Oto jak opisuje Alachnowicz swoje pierwsze wrażenie: Nad ranem ujrzeliśmy wyspe z piętrzacymi sie na niej sylwetami wieżyc cerkiewnych. [...] Krajobraz malowniczy (s. 61).

Wyspa ma od 17 do $28 \mathrm{~km}$ w przecznicy. Zadrzewiona jest lasem z jodły i brzozy, posiada około 500 jezior. Łowienie ryb w nich było surowo zabronione, ponieważ zostały zasielone ondatrą, której szaro-srebrzyste futro bardzo się ceniło.

Centralną i najważniejszą częścią wyspy był Kreml - kompleks budynków poklasztornych, otoczonych grubym murem. Dawne cerkwie, sobory, cele mnichów zostały przerobione na kazamaty, w których przebywali więźniowie. Mogli oni wyjść i wejść na zewnątrz tylko przez jedną z pięciu bram za okazaniem przepustki. Kreml wraz z otaczającymi go budynkami tworzył miasteczko. Było tam wszystko niezbędne do życia: elektrownia, cegielnia, warsztaty krawieckie i szewskie, garbarnia, fabryka mechaniczna, tartak, młyn, garncarnia, gospodarstwo rolne (uprawiano ziemniaki, kapustę, rzepę i marchew). Rybacy zaopatrywali personel administracyjny w świeżą rybę.

Alachnowicz wraz z grupą przybyłych został ulokowany w dawnym Soborze Przemienienia Pańskiego ${ }^{34}$, Sobór został podzielony na trzy piętra. Ponieważ prycz zabrakło, to grupa przybyłych więźniów ulokowała się na

33 Decyzję o powołaniu obozu na Wyspach Sołowieckich podjęły trzy osoby: Zastępca Przewodniczącego Rady Komisarzy Ludowych (RKL) Aleksiej Rykow, kierownik ds. dokumentacji RKL Nikołaj Gorbunow i osobista sekretarka W. Lenina - Lidia Fitiejewa.

34 Sobór Przemienienia Pańskiego zbudowano w latach 1558-1566 według pomysłu ihumena Filipa II, przyszłego metropolity Moskwy. Podczas budowy katedry architekci nadali mu specjalną monumentalność, wielkość, zwięzłą wyrazistość dużych form. Budowniczowie katedry stworzyli wcześniej niespotykaną kompozycję architektoniczną. Świątynia zawierała najlepsze osiągnięcia architektury rosyjskiej połowy XVI wieku. 
podłodze. Niestety, autor mało wspomina o własnym życiu na Sołowkach, ponieważ jego celem było pokazanie życia całego obozu oraz panujących tam porządków. Wspomina tylko, że tuż po przyjeździe pracował przy wyrębie drzew, ale już wkrótce otrzymał posadę suflera w teatrze ${ }^{35}$. Tam tez zamieszkał, dopóki w 1930 roku teatr nie został przeniesiony do Kiemi. Później pisarz przebywał w różnych miejscach, między innymi w muzeum, gdzie przez pewien czas piastował stanowisko stróża muzealnego, jako robotnik w magazynach, w kancelarii administracji łagru oraz jako artysta grafik w Dziale Sztuki. Dzięki tej ostatniej robocie otrzymał możliwość zamieszkania samodzielnie, z pomocnikiem, który miał za zadanie przyniesienie wrzątku i sprzątanie pokoju. Zawsze, gdzie mieszkał, starał się zachować swój ,ikonostas": półeczkę, na której stała filiżanka z talerzem oraz zdjęcie dwóch synów - Juryja i Kazimira. Na Wyspie Sołowieckiej, jak pisze autor, istniało wówczas kilka miejsc pracy: budownictwo kolei, wyrąb la$\mathrm{su}$, wydobywanie torfu, łowienie ryby, praca $\mathrm{w}$ rolnictwie oraz $\mathrm{w}$ różnych zakładach pracy.

Jak podaje Alachnowicz, w roku 1928 na Wyspie Sołowieckiej było około dziesięciu tysięcy uwięzionych. Można było spotkać przedstawicieli różnych klas społecznych i zawodów: inżynierów, agronomów, księgowych, robotników, chłopów, czekistów, księży, oficerów dawnej armii rosyjskiej, sądowników z carskich czasów, artystów, muzyków, lekarzy. Administracja zaliczała ich do kategorii „kaerzy”. Druga kategoria to „socjalnie bliscy” złodzieje, zbóje, bandyci, aferzyści, oszuści, prostytutki, łapownicy. Stosunki pomiędzy tymi dwoma kategoriami były wrogie. Więźniowie kryminalni, jak zauważa autor, czuli się w obozie o wiele lepiej od politycznych: Dla nich więzienie nie jest połaczone z przeżyciami tragicznymi, lecz jest jednym z etapów ich życia (s. 87)

Na Sołowkach były osoby tak z ZSRR, jak i z innych krajów świata, m.in. Chińczycy, Niemcy, Finowie i Węgrzy. Ci ostatni, na przykład, wyemigrowali z Węgier tuż po rewolucji, ale po paru latach pobytu w Sowietach zapragnęli jednak powrócić. Im nie tylko nie pozwolono tego zrobić, lecz aresztowano, oskarżono o szpiegostwo i zesłano na 10 lat na Sołowki.

Dużą część - 17-18\% - stanowiły kobiety: Zarówno jak mężczyźni rekrutuja się z najrozmaitszych narodowości $i$ klas społecznych, od złodziejek po damy dworu, od prostytutek do mniszek - wszystkie szczeble drabiny społecznej maja tutaj swoich reprezentantek (s. 68). Mieszkały one w oddzielnym

35 Sołowiecki Teatr został otwarty 23 IX 1923. W 1930 roku przeniesiony do Kiemi, a w 1937 r. zamknięty. 
baraku, który nosił nazwę „żeń-rota” (kobieca kompania). Zajmowały one piętrowy drewniany gmach poza murami Kremlu, na skraju cmentarza.

Chociaż, jak zaznacza autor, kobiety i mężczyźni mogli razem pracować albo spotykać się w kancelariach, jednak towarzyskie obcowanie było surowo zakazane. Nawet za krótką rozmowę, za wymianę ze sobą paru słów karano - przeważnie 14-dniowym aresztem. Mimo to kwitła prostytucja. Zdarzało się, że kobieta mogła mieć kilku kochanków: Każdy z nich nióst swojej bohdance, co mógt. Piekarz kradt chleb z piekarni, niepalacy oddawat swa racje tytoniowa, zarzadzajacy sklepikiem wynosit po kryjomu wode kolońska lub pare pończoch, tamten garść cukru, zaoszczędzonego z racji żywnościowych, inny znów dzielit się otrzymana od żony z wolności przesytka żywnościowa (s. 69). Miejscem spotkań latem służyły zarośla lasu, w zimie zaś - najrozmaitsze miejsca: kryjówki, stajnie, ubikacje, a nawet pomieszczenie „żeń-roty". Gdy urodziło się dziecko, po ukończeniu jednego roku było przekazywane do przytułku, gdzie były lepsze warunki: specjalna opieka i wyżywienie (m.in. mleko, dostateczna ilość cukru, ryż, biała pszenna mąka). Z czasem jednak, jak zauważa Alachnowicz, ich sytuacja tė̇ się pogorszyła.

Cerkwie klasztorne zostały przerobione na koszary więzienne. Do roku 1928 na Wyspie Sołowieckiej były dwa miejsca przeznaczone dla nabożeństw (jedno - dla księży, drugie - dla duchownych prawosławnych), gdzie pozwolono modlić się raz na tydzień. To drugie to nieduża szopa w lesie, w odległości kilometra od Kremla. Duchowni byli przydzieleni do nieco łatwiejszej roboty, np. pełnili obowiązki stróżów, zarządzających gospodarką więzienną. W 1928 r. nabożeństwa zostały zabronione, a wszystkich księży - katolickich i prawosławnych - osadzono w jednym miejscu - kompanii karnej. Dokonano rewizji i zabrano książki do nabożeństw, święte obrazki, krzyże. Z czasem wysłano ich na Wyspę Anzerską ${ }^{36}$, gdzie musieli ciężko pracować za małą rację żywnościową. Dopiero w 1932 roku duchowieństwo zostało rozproszone po innych miejscach, gdzie warunki życia były względnie lepsze.

Dwa razy w roku więźniowie otrzymywali ubrania: zimą - watowane spodnie i kurtki, walonki, wiosną - letnie spodnie i płócienne bluzy. Dość często znaczna ich część był już stara i prawie nie nadawała się do użycia, albo była zupełnie niedopasowana do więźnia. Wtedy trzeba było zgłosić to administracji. Ponieważ procedura ta trwała dość długo, niektórzy reperowali ubranie we własnym zakresie, mimo iż groziło to karcerem. Pewnego

36 Wyspa Anzerska - druga co do wielkości wyspa archipelagu Sołowieckiego. Z języka wepskiego tłumaczy się jako „bardzo wyciągnięta wyspa”. 
razu trafił tam również Alachnowicz: oddał buty do podzelowania swojemu sąsiadowi na pryczy, szewcowi z zawodu. Wrażenia z pobytu w karcerze na zawsze pozostały w pamięci: Więzień był pozbawiony pościeli i prycz, a spać musiat na podłodze w okropnej ciasnocie. Głowa jednego spoczywała oparta na brudnych butach sasiada, inny zmuszony byt przerzucić swe nogi przez tułów drugiego - było to nagromadzenie postaci ludzkich, rzuconych $w$ nieładzie do cuchnacej celi (s. 84).

Trzy inne miejsca, gdzie wysyłano za karę, to „Żordoczka”, Siekirka ${ }^{37}$ oraz Wyspa Kond ${ }^{38}$. „Żordoczka” mieściła się w jednej z baszt cerkiewnych. W nieogrzewanym pomieszczeniu więźniowie mieli siedzieć na wysokich ławach, by nogi nie sięgały podłogi, lecz zwisały. Ręce trzeba było trzymać na kolanach. W takiej pozycji należało przebywać cały dzień bez prawa poruszania głową i porozumienia się z sąsiadem. Zostały przewidziane trzy przerwy: jedna na przyjmowanie posiłku, a dwie inne - na wyprowadzenie w celu odbycia potrzeb naturalnych. Na wzniesieniu stała warta, obowiązkiem której było kontrolowanie, aby regulamin ciszy i nieporuszania się był przestrzegany. W przypadku złamania tych zasad więźnia związywano sznurami i wrzucano do ciemnej komórki na trzy godziny.

Siekirka to góra mieszcząca się w północno-wschodniej części wyspy. Na jej szczycie znajduje się zbudowana przez mnichów cerkiew. Duży gmach został podzielony na dwie części: parter i piętro. Na parterze osadzano za mniejsze przestępstwa, np. kradzież, bójkę. Więzień miał prawo zachować pościel i ubranie. Kara polegała na zmniejszeniu racji żywnościowej, a najgorsze - przebywaniu w nieogrzewanym pomieszczeniu. Na górze więźniowe nie mieli prawa do pościeli i byli rozebrani do bielizny. Osadzano tu przeważnie oskarżonych o próbę ucieczki i przestępców politycznych. Niestety, nie wszyscy mogli wytrzymać takie męki: trafiali albo do szpitala, albo na cmentarz.

Z kolei Wyspa Kond znajdowała się w odległości 130 km od Wyspy Sołowieckiej. Wysyłano tam inwalidów i osoby niezdolne do pracy. Aby uniknąć ciężkiej pracy i nieznośnych warunków życia odmrażali sobie dolne kończyny albo dobrowolnie okaleczali się. Większość z nich nie było w stanie tam przetrwać i umierała. Ludzie moga zginać - kogoż to może obchodzić! Żyjac w ciagtym niebezpieczeństwie, dziesiatkowani przez choroby, wycień-

37 Góra Siekirna (Секирная Гора, potocznie - Siekirka/Секирка) - wzgórze na Wyspie Sołowieckiej o wysokości 73,5 metra. Na szczycie mieści się świątynia-latarnia Cerkiew Wniebowstąpienia Pańskiego.

38 Wyspa Kond (Кондостров) - wyspa w Zatoce Oneskiej Morza Białego. Od 1920 roku była w składzie obozu Sołowieckiego. 
czenie i głód, będac pod ciagła groźba rozstrzelania, więzień sowiecki przyzwyczait sie lekko cenić życie ludzkie. Dusza zczerstwiała, egoizm zapanowat wszechwladnie, zatracity sie wszelkie wyższe uczucia ludzkie w rodzaju litości, wspótczucia itp. (s. 103) - rozważał Alachnowicz. Wśród przebywających na Sołowkach dość spory odsetek było ludzi chorych: Oprócz chorób wenerycznych choruja na szkorbut, gruźlice, czyraki, nie liczac wybuchajacych od czasu do czasu epidemii tyfusu (s. 74).

W związku z tym śmiertelność była dość wysoka. Kiedy o godzinie piątej nad ranem otwierała się główna brama, wyjeżdżał wóz z wielką skrzynią. Mogła ona pomieścić osiem trupów. Pogrzeb odbywa się na dawnym klasztornym cmentarzu, w pobliżu murów Kremla. Tam wykopano jama, w której mogło się zmieścić do dwustu trupów. Sanitariusze zrzucali trupy ze skrzyni, a jamę przykrywali deskami. Gdy jama się zapełniała, zasypywano ją ziemią.

Na przykład, jesienią 1929 r. wybuchła epidemia tyfusu. Gdy szpital został przeludniony, chorych kierowano do innych pomieszczeń. Wstrzymano roboty w przedsiębiorstwach. Podjęto decyzję o zamknięciu na dwa tygodnie tych cel, w których przebywała chora osoba. Mimo to epidemia objęła całą wyspę i dochodziły wieści o niebywałych rozmiarach katastrofy. Jak tylko zaczęły się mrozy, podjęto radykalne środki: wydano nakaz opuszczenia celi i rozpoczęto sprzątanie. Co tydzień wszyscy musieli iść do łaźni, strzyc się i zakładać czystą bieliznę. Dopiero wiosną 1930 roku udało się przezwyciężyć epidemię. Ludność wyspy zmniejszyła się wtedy o połowę. Sami więźniowie nie poruszali tematu śmierci. Zamiast skazany na śmierć mówili pojechat na badania do Dzierżyńskiego lub przejechać się na księżyc.

Zdarzało się, że niektórzy próbowali uciec. Marzenie o powrocie do domu i rodziny czasem brało górę nad rzeczywistością: Marzenia o życiu spokojnym, bez ciaglego strachu. [...] Marzenie o jakimś innym życiu. Marzenie o cieple, o słońcu, o życiu sytym, czystym, beztrwożnym... (s. 105). Na przykład, wiosną 1929 roku aresztowano około 70 osób pod zarzutem zmowy mającej na celu przejęcie jednego ze statków, kursujących między Sołowkami a lądem. Po pewnym czasie 30 osób zwolniono. Jednak nikt z nich nie miał prawa opowiedzieć o szczegółach tego procesu.

Połączenie z lądem odbywało się dzięki dwóm statkom: „Gleb Boki” oraz „Klara Cetkin”. Nawigacja zwykle zaczynała się po koniec maja, a kończyła się w grudniu. Zanim więzień zostanie ulokowany w jednej z jednostek („filia”), musiał odbyć kwarantannę. Z czasem brakowało miejsc, i wtedy nowe osoby lokowano w stajniach i chlewach. Zimą nawigację utrzymywały hydroplany, które przewoziły członków administracji i dokumenty. 
Zadaniem obozu, jak podkreśla autor, było wychowanie więźnia („перевоспитание"). W tym celu wykorzystano różne środki: lekcje wychowania politycznego (wbijano im pojęcia o klasowości, informacje o osiągnięciach Rewolucji Październikowej i konstytucji), rozmowy z wychowawcami, gazetka ścienna oraz „красные уголки” (umieszczano tam popiersie Lenina, na ścianach wisiały hasła, na stole leżało czerwonem sukno, a na nim leżały radzieckie czasopisma).

Kiedy nadchodziła wolna chwila, więźniowie próbowali się bawić. Stosowana przez nich gra zazwyczaj połączona była z pragnieniem demonstracji swojej siły z agresją, a nawet z fizycznym znęcaniem się. Na przykład, popularna gra „Grzebanie baby” polega na tym, że ofiara miała się położyć na podłodze, inni zaś musieli ją bić skręconymi ręcznikami. W grze „Rower” śpiącemu wkładano między palce nóg kawałki papieru i podpalano jego. Ofiara z bólu budziła się i wykonywała ruchy podobne do ruchów cyklisty. U jednych taka zabawa wywoływała śmiech, a u drugich wściekłość.

Człowiek tak prędko przystosowuje sie do nowych, nienormalnych warunków życia, wrodzona człowiekowi potrzeba śmiechu tak bezwzględnie dopomina się o swoje prawa. [...] Człowiek w niewoli śmieje się sam i ośmiesza swych władców. Może zawdzięczając tej zdolności śmiechu człowiek jest $w$ stanie przystosować się do najokropniejszych warunków życia, może śmiech właśnie czyni czlowieka odpornym na wszelkie przeciwności losu (s. 86) - zastanawia się Alachnowicz. Zauważa: Całe życie obozu toczy sie pod znakiem ohydnego przekleństwa rosyjskiego. Klna, budzac się ze snu, klna, idac do pracy, wracajac z pracy, klna, wystajac w kolejce w oczekiwaniu przed kuchnia obiadu, klna, cieszac sie, klna, smucac się, klna w każdej okazji życia (s. 73).

Porównując mężczyzn i kobiety stwierdza: Kobieta zawsze $i$ wszędzie odznacza się większa swarliwościa, niż mężczyzna, w przeklenstwa swe wkłada pewne smakoszostwo, lubowanie wyrazami, podczas gdy mężczyzna klnie, $\dot{z} e$ tak powiem, bardziej odruchowo, nieświadomie, nie wnikajac w treść wyplutego przekleństwa... (s. 73)

Jak wspomina autor, przez siedem lat pobytu na Sołowkach tylko trzy razy słyszał o popełnionym samobójstwie: Wszyscy goraczkowo chwytaja sie życia. Czym życie jest okropniejsze, tym więcej ma ono powabu, lepsze najgorsze życie niż śmierć. Bo tu jeszcze sa jakieś nadzieje, tam już nadziejom miejsca nie ma. I żyja ludzie nadziejami, często dziecinnymi, zwodnymi, które już wielokrotnie ich oszukały, a jednak wierza (s. 85). Jedni wierzą w amnestię, drudzy - w zmianę kodeksu karnego, trzeci - w życzliwość administracji łagru. 
Administracja obozu w znacznej części składała się z gepistów, którzy zostali zesłani na Wyspy Sołowieckie za jakieś drobne przewinienia służbowe. Za poważniejsze przestępstwa trafiali tu już jako więźniowie (otrzymywali od 3 do 10 lat), ale też mieli możliwość pełnienia różnych funkcji. Najczęściej byli tajnymi współpracownikami ( „seksoci”, секретные сотрудники) ISO (Inspekcyjno-Śledczy Oddział). Mieli oni za zadanie śledzenie i donoszenie na osoby, które „bez szczególnego entuzjazmu” odnosili się do pełnienia swoich obowiązków, a co najważniejsze - mieli „kontrrewolucyjne" poglądy. Ponadto sporządzali charakterystyki więźniów na podstawie tajnych donosów, przeprowadzali egzekucje (w przypadku gdy Kolegium GPU w Moskwie wyda wyrok śmierci). Obecność „seksotów” powodowała, że wzrastało poczucie niebezpieczeństwa i człowieka opanowywał strach: Ci, co sie modla, robia to w skrytości, ci, co chca uczynić sobie zwierzenia przyjacielskie, czynia to szeptem, ogladajac sie, by niepożadane ucho nie pochwyciło oddzielnych zdań $i$ nie wysnuło $z$ nich przy pomocy własnej fantazji jakiegoś oskarżenia. Jeżeli trafnym jest przysłowie: „Ściany maja uszy", to nigdzie nie można zastosować go trafniej, jak tutaj właśnie (s. 76).

Gdy „seksoci” podejmują decyzję o wszczęciu sprawy, oskarżony natychmiast zostaje przeniesiony do izolatora. To specjalne pomieszczenie, w którym więzień jest sam i nie ma możliwości kontaktu z innymi osobami. Nie wolno mu palić, a racja żywnościowa jest zmniejszona. Zdarza się, że zostaje zgnębiony moralnie. Polega to na tym, że śpiącego budzą w nocy i pytają o imię i nazwisko. Oznacza to, że wkrótce zostanie rozstrzelany. W latach 1927-1930 egzekucje odbywały się przeważnie o zmroku. Wówczas całe życie w obozie zostaje wstrzymane. Urzędnicy ISO wyprowadzają skazańców w bieliźnie z zawiązanymi rękami. Rozstrzeliwano przy świetle latarek. Skazaniec stawał nad brzegiem wykopanego dołu, a współpracownik ISO wykonywał strzał. Po 1929 roku miejsce egzekucji przeniesiono do izby dezynfekcyjnej, położonej w obrębie murów Kremla. Z tej izby nie było słychać strzałów. Po egzekucji wozem odwożono trupy na cmentarz. Nieco później miejsce kaźni przeniesiono o $10 \mathrm{~km}$ od Kremla.

Znaczna część dozoru składa się z więźniów. Tylko kilkadziesiąt osób stanowiła nadzór wolny - tzn. ci, którzy zostali tu skierowani. Reszta zaś to czekiści lub bolszewicy wojskowi, którzy popełnili przestępstwa, ale otrzymali możliwość pełnienia funkcji odpowiadających ich specjalności. Wszyscy byli ubrani w długie sowieckie szynele (różnili się tylko tym, iż pierwsi mieli na kołnierzyku czerwoną odznakę, a drudzy - czarną) i byli uzbrojeni w karabiny. Trzeba przyznać - podkreśla Alachnowicz - że ci niewolni dozorcy byli bardziej srodzy, bardziej wymagajacy $i$ znacznie mniej humanitarni w stosunku do swoich uwięzionych towarzyszy, niz dozorcy wolni (s. 64). 
Co roku, jesienią, na Sołowki przyjeżdżała specjalna komisja na czele z Glebem Bokim ${ }^{39}$ - opiekunem obozu Sołowieckiego z ramienia rządu. Jej zadaniem było rozpatrzenie spraw, dotyczących skrócenia terminu - o pół roku albo rok, a czasem o dwa lata. Lista takich osób wcześniej była ułożona przez miejscowe kierownictwo, dlatego każdy chciat wysunać się na widoczne miejsce, przypodobać się swej władzy, zyskać jej sympatie (s. 65).

W 1930 roku sytuacja na Sołowkach uległa zmianie. Stało się to za sprawą pięcioosobowej komisji - która miała sprawdzić funkcjonowanie obozu. $\mathrm{W}$ tym celu odbyto liczne rozmowy z więźniami. W rezultacie aresztowano kilkaset osób - członków administracji. Prawie połowę (przeważnie z grona więźniów) rozstrzelano, a resztę (wolni) zesłano na okres od 5 do 10 lat do innych obozów. Jeden z kierowników Sołowków - Zaryn został skazany na dziesięć lat. W pracy obozu zaszły zmiany: skasowano Siekirki, zaprzestano bicia więźniów, poprawiły się warunki sanitarne. Zastanawiając się nad przyczynami tych zmian, Alachnowicz wraz z grupą kolegów doszli do wniosku, że: Znajac polityke Sowietów, skłonni byliśmy przypuszczać, że w tym przypadku mamy do czynienia z pewnego rodzaju „inscenizacja”, obliczona na efekt zewnętrzny. Przypuszczaliśmy nawet, że coś niecoś o życiu Sotowkow przeniknęło do prasy zagranicznej i srogie rozprawienie sie komisji $z$ rzekomo winnymi miało na celu wykazanie, że Sowiety dbaja o humanitarny stosunek do więźnia w myśl głoszonej przez nich zasady: „nie karać, lecz poprawiać" (s. 98).

Ale z czasem stało się jasne: było to rezultatem dyrektywy z góry. Politycznych stopniowo usuwano ze wszystkich stanowisk administracyjno-gospodarczych, a większe przywileje otrzymywali kryminaliści. Przyczyniło się to do tego, że rozpoczęła się plaga kradzieży. Kradziono wszystko: pieniądze, tytoń, ubranie, bieliznę, artykuły żywnościowe. Z czasem został ujawniony fakt, iż jeden z naczelników obozu Sołowieckiego, Mordwinow, wraz z kilkoma pracownikami ISO był w kontakcie ze złodziejami. Ci ostatni byli pobłażliwie traktowani ze strony władzy i musieli dzielić się swoim łupem.

System napędzania do pracy i wyzyskiwania siły ludzkiej do ostatecznych granic, stosowany na Sołowkach, zdaniem Alachnowicza, nie dawał oczekiwanych wyników. Dość często zdarzały się sytuacje, kiedy zadanie nie zostało spełnione na czas. Wtedy odpowiedzialna za to osoba była de-

39 Gleb Boki (1879-1937) - działacz komunistyczny, funkcjonariusz OGPU Federacji Rosyjskiej. W latach 1921-1936 szef Wydziału Specjalnego (kryptografa, szyfry, radiowywiad, radiokontrwywiad oraz zabezpieczenie tajemnicy w urzędach). 16 V 1937 aresztowany, a 15 XI 1937 skazany na śmierć i rozstrzelany. 
gradowana albo karana. Przyczyn nie wywiązywania się z zadań, według autora, było kilka: po pierwsze, zesłani na Sołowki ludzie byli oderwani od swoich bliskich i utracili kontakt ze swoim krajem, po drugie, nie zostały stworzone dla nich odpowiednie warunki życia i pracy, po trzecie, uzależnieni od woli i decyzji dziesiętników i dozorców, po czwarte, ciągły przymus i strach przed zostaniem ukaranym (Kij nie pomoże tam, gdzie istnieje tylko przymus pracy [s. 65].)

Początkowo więźniowie mieli jeden wolny dzień - niedzielę. Jednak z czasem został on skasowany, a dzień odpoczynku mógł przypadać na dowolny dzień tygodnia. To spowodowało, że więźniowie zatracili poczucie czasu.

Wkrótce po przybyciu na Sołowki Alachnowicz zetknął się z tym, że panował tam system upokarzania, wykorzystywania, zastraszania jednej osoby przez drugą: Każdy, kto posiadat jakakolwiek władze, gnębit swoich podwładnych: dziesiętnik był bez litości dla zwyktego robotnika, zarzadzajacy przedsiębiorstwem byt postrachem dla catego etatu podlegtych mu pracowników (s. 64). Dlatego wielu więźniów starało się przypodobać swojemu zwierzchnikowi i uzyskać jakieś ulgi - w postaci dodatkowej porcji żywności, zezwolenia na mieszkanie nie w celi, lecz w jakimś lepszym miejscu, lub trafieniu na listę osób, którym skracano termin karny.

Jak podkreśla Alachnowicz, początek jego pobytu w obozie przypadł akurat na okres NEP-u i jeszcze nie znano głodu w obozie. Karmiono wtedy soczewicą, kaszą gryczaną, ziemniakami, a czasem gotowano zupę na mięsie. Jednak po 1930 roku sytuacja się zmieniła: Kartofle stały się rzadkościa, o grochu, kaszy gryczanej $i$ soczewicy pamięć już dawno zaginęła, pozostała tylko ryba solona, tzn. „tarań”, która karmiono nas na śniadanie $i$ obiad. Gotowano z tej ryby solona polewke, troche zaprawiona kasza z prosa, lub solonymi pomidorami, bardzo rzadko kartoflami (s. 128). W sklepikach rzadko pojawiały się artykuły spożywcze: Czasem pojawi się beczka gnijacych śledzi, które znajduja chętnych nabywców. Chleb jest zaś ściśle normowany $i$ w handlu się nie spotyka (s. 139).

Część osób nie wstydziła się grzebać w śmietnikach. Zbierano główki od śledzi i ości od „tarani”, z czego gotowano zupę dodając do niej pokrzywy. W okresie letnim (lipiec-sierpień) zbierano czernice, borówki i grzyby, które obficie rosły w lasach sołowieckich.

Przebywający na Sołowkach więźniowie mieli możliwość spotkania się z krewnymi. Istniały dwie możliwości. Pierwsza: goście mogli mieszkać w przeznaczonym na ten cel domku i spotykać się z więźniem raz dziennie przez dwie godziny w obecności przedstawiciela administracji. Druga: więzień otrzymywał pozwolenie zamieszkania wraz z krewnymi przez 7-14 dni 
i spędzania z nimi wolnego czasu bez ograniczeń. Istniała również możliwość prowadzenia korespondencji z członkami rodziny:

Jakaż to radość niewymowna, jakież to szczęście bezmierne zimą na tej przeklętej, odciętej od świata wyspie otrzymać list od kogoś, kto cię kocha, tęskni, bezsilnie boleje nad twym losem, stara się dodać ci sił do wytrwania, osłodzić życie nadzieją... [...] Inni czytają po parę razy, nie mogąc się nasycić słowami, pisanymi drugą ręką. Poprzez lody, szurgę, torosy, poprzez śniegi otrzymali ten kawałek papieru, zapisany wyrazami, które, starając się zmylić czujność cenzury, podają wiadomość o tym, co się dzieje pod strzechą rodzinną (s. 104).

W okresie nawigacji listy były przewożone łodziami do Kiemi, a następnie przekazywane dalej. Najgorzej było w okresie zimowym. Osoby, które zgadzały się na ochotnika dopłynąć do lądu, nazywano „pomorami”. Po otrzymaniu prowiantu (takiego samego, jak ci, którzy wykonywali najcięższe roboty) na dwa tygodnie wyruszali w podróż w sześcioosobowych łodziach. Mimo trudnych warunków klimatycznych powinni byli dotrzeć do Kiemi. Na swojej drodze spotykali liczne przeszkody, przede wszystkim byli „zdani na łaskę i niełaskę wiatrów”. Zdarzało się nawet, że wiatr pędził łodzie aż ku ujściu Morza Białego do Oceanu Lodowego, i wtedy nie było żadnych szans na uratowanie życia.

Niestety, nie wszystkie tematy można było poruszać w korespondencji. Więźniowie nauczyli się czytać między wierszami. Jeśli ktoś pisze, że „siostra jest chora i leży w szpitalu", to oznacza, siedzi w więzieniu, „zdrowie brata wymaga dłuższego pobytu w uzdrowisku" - brat powędrował do obozu koncentracyjnego. Zdarzało się, że niektórzy pisali otwarcie, bez użycia jakiegoś specjalnego kodu. Dzięki temu więźniowie dowiadywali się o głodzie i ludożerstwie na Ukrainie.

Na Sołowkach funkcjonowało kilka instytucji kultury i sportu: biblioteka, muzeum, kino, teatr i boisko. Muzeum miało trzy działy: przyrodniczy, przemysłowy i historyczny. Najciekawszym był dział historyczny: w jego zbiorach zgromadzono cenne ikony, krzyże oraz inne relikwie. Mieściły się tam także prochy św. Zozyma i św. Sawwacjusza ${ }^{40}$ - założycieli klasztoru Sołowieckiego. Zwiedzanie muzeum było możliwe wyłącznie w grupie z przewodnikiem oraz z wychowawcą. W 1933 roku, gdy odbyła się reorganizacja muzeum, dział ten został zamknięty. Dwa razy w tygodniu chętni

40 Św. Zozym i św. Sawwacjusz - dwaj z trzech (trzeci - św. German) założycieli Klasztoru Sołowieckiego. Jak twierdzi legenda, głównym twórcą klasztoru był jednak św. Zozym. 
mogli odwiedzać kino. Biblioteka miała bogaty księgozbiór: zarówno literatura $\mathrm{w}$ języku rosyjskim, jak i w innych europejskich językach. Od czasu do czasu odbywała się rewizja: usuwano te tytuły, które były podejrzane pod względem ideologicznym. Natomiast książki w innych językach obcych pozostawały i były dostępne. Na boisku latem uprawiano gry sportowe, a zimą urządzano ślizgawkę. Ponadto można było jeździć na nartach i saneczkować.

Ważne miejsce w życiu obozu zajmował teatr, w którym przez pewien czas pracował Alachnowicz. Powstał on w 1927 roku z inicjatywy jednego z aktorów. Przerobiono na niego dawną stołówkę klasztorną i mógł on zmieścić ponad 500 osób. Wśród więźniów byli aktorzy, muzycy, soliści operowi, baletnicy, rekwizytorzy, którzy chętnie podjęli się pracy. Przez pewien czas niestety nie byli oni zwalniani z obowiązku pracy. Próby odbywały się późnym wieczorem albo w nocy. Kostiumy i scenografię szyto ze starych worków. Jednak z czasem, w miarę tego, jak teatr cieszył się coraz większą popularnością, administracja podjęła decyzję o stworzeniu etatów dla grupy aktorów i zwolnieniu ich z przymusowych robót. Z czasem nawet zorganizowano orkiestrę. Oczywiście impreza na razie przewidywała nie wptyw kulturalny na uwięzionych, lecz rozrywke dla „władzy”, która na tej przeklętej wyspie, gdzie lato trwa zaledwie dwa miesiace, nie miała dotychczas innej uciechy oprócz pijaństwa i polowania (s. 121) - zaznacza Alachnowicz. Pracownicy teatru otrzymali możliwość zamieszkania w ciepłej celi poklasztornej. Przedstawienia odbywały się cztery razy tygodniowo - dwa pierwsze bezpłatne, a dwa kolejne - płatne.

Ważnym wydarzeniem, które na długo pozostało w pamięci więźniów, było nakręcenie filmu o codziennym życiu na Sołowkach ${ }^{41}$. Miało to miejsce w latach 1927-1928, a reżyserem był A. Czerkasow. W tym czasie na Zachodzie ukazało się kilka publikacji o Sołowkach i władza radziecka postanowiła za wszelką cenę udowodnić, że przedstawione przez ich autorów fakty są kłamliwe. Jak wspomina Alachnowicz, pewnego razu komendant obszedł cele i wybrał osoby, które miały przyzwoity wygląd. Zdjęcia odbywały się w małym ogródku, gdzie ustawiono stoły i grała orkiestra więzienna. Więźniowie (kobiety i mężczyźni) mieli siedzieć przy stołach, rozmawiać, czytać radziecką prasę albo grać w szachy: Sytuacja była tak niezwykta, że śmiechom $i$ chichotom nie było końca, toteż film sie udat: ukazat obraz radości sołowieckiej. Ogladaliśmy potem radosne wlasne miny, patrzyliśmy, jak raźnie i dziarsko wychodzimy rano na roboty, jak wesoło pracujemy, jak

41 Соловки (в 7 частях), https://www.youtube.com/watch?v=O0UJGJwGX1E (dostęp w dniu 24 VIII 2019). 
odpoczywamy po pracy, oddajac sie kulturalnym rozrywkom (s. 127). Film miał wyłącznie propagandowy charakter. Był pokazywany we wszystkich zakątkach ZSRR oraz zagranicą. Obejrzała go także matka Alachnowicza, o czym napisała w liście do niego: Widziałam w kinie wasze życie na Sotowkach. Uspokoitam się znacznie. Widze, że tam nie jest tak źle, jak myślałam (s. 127).

Drugim, oprócz udziału w filmie, znaczącym wydarzeniem na Sołowkach była wizyta Maksima Gorkiego ${ }^{42}$. Informacja o jego przyjeździe, jak podkreśla Alachnowicz, wywołała radość wśród inteligencji. Dla wielu z nich ideały wolnościowe były wciąż bardzo bliskie i drogie, wielu z nich, jak i Gorki, walczyło z samodzierżawiem rosyjskim, tułało się po więzieniach carskich i marzyło o wolnej Rosji. Nie był wyjątkiem także sam autor opowieści, który, jak wyznał, zaczytywał się jego utworami. Ponadto Gorki, jego zdaniem, posiadał niezwykty urok dzięki dą̇̇eniu ku wolności, częstym konfliktom z władza, a także dzięki niezwykłej, petnej przygód młodości (s. 123). $\mathrm{Na}$ jego cześć przygotowano koncert. Oto jak opisuje Alachnowicz spotkanie z pisarzem: Twarz Gorkiego wyrażała bezbrzeżna nudę. Siedział lekko przygarbiony i obojętnym wzrokiem patrzył na estrade, skad plynęly dźwięki muzyki, pieśni, „czastuszki” - całego programu, ułożonego ku jego czci. [...] Jakie wrażenie odniósł z Sołowiek? - zadawaliśmy sobie pytanie. Jakie relacje zamieści w pismach po swym powrocie z wyspy Solowieckiej? - zapytywaliśmy siebie w swej naiwności (s. 124).

$\mathrm{Na}$ szczęście nikt z obecnych na koncercie nie wiedział, że w artykule, zamieszczonym na łamach moskiewskiego dziennika „Известия”, literat pochlebnie odzywał się o władzy, która stworzyła bardzo dobre warunki dla więźniów. Należy także dodać, że sam Alachnowicz wspomina o tym, że przed 1930 rokiem więźniowie mieli wolny czas, podczas którego mogli czytać, grać w szachy albo nawet wychodzić za granicę Kremla na spacer do lasu.

W piątej, przedostatniej części opowieści, Alachnowicz opisał swój pobyt $\mathrm{w}$ mieście Kiem. Było ono znane z tego, że mieścił się tam Główny Zarząd Obozów Sołowieckich (USŁAG / УСЛАГ - Управление Советскими Лагерями). Drewniane baraki, otoczone drutem kolczastym, znajdowały się poza miastem. Warunki życia były gorsze niż na Sołowkach. Jedna część więźniów pracowała w warsztatach stolarskich, krawieckich oraz kancelarii, obsługującej obozy Sołowieckie, druga zaś na miejskich przedsiębiorstwach

42 Sam M. Gorki podaje daty 20 i 21 VI 1926. Natomiast A. Sołżenicyn po zbadaniu dzienników pisarza twierdzi, że wizyta Gorkiego trwała do wieczora 23 czerwca. 
(elektrownia, drukarnia, garbarnia, fabryka zabawek). Ci ostatni otrzymali przepustkę umożliwiającą im wyjście do miasta. Nie mieli oni prawa kontaktu z miejscową ludnością. Odżywianie było takie, jak na Sołowkach.

Co drugi dzień ukazywała się gazeta „Трудовой Путь” („Droga Pracy"), wydawana przez więźniów. Zamieszczane tam teksty miały wyłącznie charakter propagandowy: nawoływano w nich do rzetelnej pracy i krytykowano wszystkie plagi. W każdym baraku i przedsiębiorstwie znajdował się radioodbiornik. Emitowane przez niego programy miały za zadanie zachęcać do pracy, zmuszać do wzorowania się na najlepszych pracownikach, a zarazem potępiać i zastraszać tych, którzy nie wywiązują się ze swoich obowiązków. O godzinie drugiej w nocy były reportaże z krajów europejskich - Warszawy, Wiednia, Berlina i Pragi:

Dziwne wrażenie po tych ciągłych głosach o „udarniczestwie i soriewnowanii” wywierają dźwięki fokstrota, słyszane z jakiejś kawiarni europejskiej. $\mathrm{W}$ przerwach słychać brzęk szkła, gwar rozmów... Głodny, obdarty więzień słucha tych dźwięków, marząc o życiu sytym, w czystości, nie o komforcie, lecz o najbardziej elementarnych wymaganiach życia po ludzku. Wszystko to dalekie, niedoścignione... Płyną marzenia naiwne o czystym kołnierzyku, o stroju europejskim, o eleganckich kobietach, o jasno oświetlonej sali, o kwiatach... Płyną marzenia o tym wszystkim, co na zawsze stracone. [...] Stoi więzień oparty o ścianę i słucha. Marzy... Hej, łza się zakręciła w oku. Dobrze, że nikt nie widzi: śpią towarzysze (s. 144).

13 lipca Alachnowicz został wezwany do ISO, skąd zaprowadzono go do izolatora. Nie mógł zrozumieć, za co został ukarany: Co się stało u licha? Przez cały czas pobytu w obozach Sołowieckich ani razu nie byłem więziony $w$ izolatorze, teraz dopiero, w siódmym roku odbywania kary, los dat mi skosztować i tego! Zapewne jakieś nieporozumienie! [...] Najrozmaitsze przypuszczenia tlukty sie po mej głowie jak stado wróbli, złapanych do klatki. Ach, ta niepewność!... jakie to męczace! (s. 146)

Jednak po dwóch dniach został wypuszczony z izolatora, otrzymał osiem ryb, półtora kilograma chleba i w towarzystwie dwóch żołnierzy został odwieziony na dworzec kolejowy. Przez Leningrad w dniu 17 lipca dotarł do Moskwy. Gdy został przywieziony do więzienia Butyrki, był przekonany, że to Łubianka, i z lekka się z tego cieszył: podświadomie marzył zobaczyć to miejsce na własne oczy. W Butyrkach spędził kilka miesięcy. Miał okazję poznać ludzi, którzy jak i on, zostali oskarżeni o nie popełnione przestępstwa (najczęściej byli to chłopi) i zesłani do obozów koncentracyjnych. Nie będąc w stanie pogodzić się ze swym losem postanowili uciec. Jednak zostali złapani i dostarczeni do moskiewskiego więzienia, aby stanąć przed sadem i otrzymać nową karę. 
Wśród więźniów byli także rodacy z Polski, między innymi dwójka robotników z huty szkła z Wilna. Przekroczyli oni polsko-białoruską granicę pod wpływem propagandy „budownictwa socjalistycznego”. Był także robotnik z Łodzi, który przybył do ZSRR w składzie delegacji i zafascynowany Rosją postanowił zostać. Jednak kiedy zaczął wypowiadać krytyczne spostrzeżenia, trafił do więzienia. Wszyscy oni żałowali tego, że poddali się propagandzie. Jednak byli również tacy, którzy nie mieli nienawiści do radzieckiej władzy, mówili: Dobrze mi tak... wtadza wie co czyni... bytem staby, wahatem się... [...] zreszta, co znaczy moje jedno życie albo $i$ tysięcy nawet takich, jak ja, w porównaniu z tym wielkim budownictwem (s. 155).

W Butyrkach Alachnowicz także dowiedział się o nowych metodach i sposobach, stosowanych przez GPU podczas przesłuchania. W drugiej połowie lat 20. nie stosowano przymusu fizycznego. Natomiast już na początku lat 30. zaczęto aktywnie wdrażać w życie ten sposób znęcanie się. Najbardziej popularny był „konwejer”. Polegał on na tym, że osobie podczas przesłuchania odmawia się prawa do snu. Śledczy wymieniają się jeden po drugim, a ofiara ma możliwość zdrzemnięcia tylko na pięć-dziesięć minut. Gdy więzień nie wytrzymuje i zasypia, zostaje oblany zimną wodą. Zdarzało się, że taka praktyka trwała przez siedem dni. Myśli się maca, zapomina się znaczenia wyrazów. Zamiast imion osób placza się na ustach nazwy geograficzne. Zdaje się, że na głowie nasadzono jakaśs czapkę żelazna. Parokrotnie chwytałem sie za głowe, pragnac zdjać ja, i byłem zdziwiony, gdy dłonie dotykały moich własnych włosów... Pragnienie snu jest tak niepomierne, że nie da sie wypowiedzieć (s. 156) - wyznał autorowi jeden z więźniów.

Ponieważ pobyt w Butyrkach się przedłużał, niepokój oraz poczucie niepewności coraz mocniej ogarniało Alachnowicza. Miał kilka wersji: wytoczenie nowej sprawy, przeniesienie do innego obozu albo wymiana i powrót na ojczyznę. Wreszcie nastąpił ten dzień: 4 września Alachnowicz został zaprowadzony najpierw do fryzjera, następnie do łaźni, a potem do celi jednoosobowej. Dano mu sporą miskę kaszy, czajnik z herbatą, dziesięć papierosów, poduszkę i czystą pościel. Po kilku godzinach otworzyły się drzwi i gepista poinformował go o tym, że zostanie przekazany władzy polskiej. Następnego dnia odwieziono go do Mińska, gdzie dano mu możliwość spotkania się z matką.

Będąc na stacji granicznej Kołosowo, Alachnowicz zwrócił uwagę na napis, który wisiał na przejściu granicznym: „Socjalizm zetrze wszystkie granice". Pamięta ten plakat doskonale, kiedy przekraczał granicę w listopadzie 1926 roku i jechał na Białoruś z wiarą w możliwość prowadzenia „białorutenizacji”. Dziś wracam, tułacz, w buszłacie więziennym, otrzeźwiony So- 
towkami, uszczęśliwiony, że za chwile noga moja przestapi granice państwa budujacego sie socjalizmu. Dziś jest jesień, lecz w duszy mej rozkwita jakaś nieopisana radość... [...] ja podażam na zachód, do państw „kapitalistycznych", gdzie będe mógt spać spokojnie, wiedzac, że w nocy goście z GPU nie zapukaja do drzwi mojego mieszkania (s. 164-165) - wspomina ostatnie chwile na ziemi białoruskiej Alachnowicz. Przypomniały mu się słowa Miguela Cervantesa da Saavedry, który po wyjściu z niewoli u angielskich piratów powiedział, że największym szczęściem, jakiego człowiek może doznać na ziemi, jest radość z odzyskanej wolności. Tego wtaśnie szczęścia doznatem dn. 6 września 1933 roku. Mówię o swojej radości. Dziękuję... Dtawię się stowami... Coś mnie ściska za gardło ze wzruszenia... [...] Ta chwila juź więcej się nie powtórzy. Raz tylko w życiu sie ja przeżywa (s. 166) - pisze Alachnowicz.

\section{Wydanie w języku białoruskim: „У капцюрох ГПУ” (1937)}

Białoruska wersja wspomnień ukazała się drukiem w 1937 roku. Na okładce zamieszczono rysunek przedstawiający klasztor na Wyspach Sołowieckich oraz dwa zdjęcia autora: jedno z 1929 roku podczas jego pobytu w łagrze, drugie aktualne - z 1937 roku.

Przygotowując publikację do druku, Alachnowicz, po pierwsze, dokonał nieznacznych zmian (m.in. połączył niektóre rozdziały i dodał nowe), po drugie, rozszerzył opowieść o jedną część pt. Witebsk, w której przytoczył wydarzenia, poprzedzające jego areszt. Składa się ona z trzech rozdziałów: Папутиік (Pориtсzyk), Філёр (Filer) oraz Думкі (Refleksje). Została wprowadzona nowa postać - Poputczyk, która ma autobiograficzne cechy.

W pierwszym rozdziale, Poputczyk, przytoczono rozmowe z pracownikiem GPU, który odwiedził literata w dniu 31 grudnia 1926 w Witebsku. Miało to miejsce wieczorem, niedługo przedtem, jak ten miał się udać do aktorów Białoruskiego Teatru Narodowego-2 (BTN-2), z którymi planował świętować sylwestra. Osoba ta poprosiła Alachnowicza o wyjazd do Mińska następnego dnia, 1 stycznia, aby jak najszybciej spotkać się z zastępcą głównego inspektora wojsk GPU Józefem Opańskim. W przypadku trudności finansowych zaoferował mu nawet pieniądze. Po jego odejściu Alachnowicz rozważa: Jacy sa mili ludzie! Gentelmani! Co za proste, szczere relacje! Nieznany człowiek niczym dobry znajomy proponuje mi pożyczyć pieniadze. Co za mili ludzie! (s. 4-5) Pisząc te słowa, Alachnowicz, jak mi się wydaje, nie wstydził się pokazać czytelnikowi, że był osobą nieco naiwną i łatwowierną. Przez pierwsze kilka miesięcy pobytu na Białorusi nie 
dopuszczał on myśli, że zostanie aresztowany, a tym bardziej oskarżony o jakieś przestępstwa.

W kolejnym rozdziale, Filer, opisał areszt podczas jazdy nocnym pociągiem do Mińska. Po wejściu do wagonu do literata podszedł elegancki mężczyzna, poinformował go o areszcie i kazał zająć miejsce niedaleko siebie. Przez całą noc pies nieznajomego - Filer - pilnował go przed ewentualną ucieczką. Alachnowicz był tak zszokowany tą sytuacją, że nie był w stanie zmrużyć oczu, a w głowie nurtowały go różne pytania: $Z a$ co?... To chyba jakieś nieporozumienie! Za co jestem aresztowany? Przecież zmienitem swój stosunek do Sowietów! Już dawno nie krytykuje ani słowem, ani piórem! Przeciė̇ jestem „poputczykiem”! Przyjechałem tu legalnie!... Czego oni jeszcze ode mnie chca? (s. 7)

$\mathrm{W}$ trzecim, ostatnim rozdziale pierwszej części autor dzieli się z czytelnikiem refleksjami na temat przyjazdu na Białoruś i swojego aresztu. Stwierdza, że dużo słyszał o pozytywnych zmianach, jakie zachodzą na Białorusi, o powstaniu kilku scen Białoruskiego Teatru Narodowego, o szerzącej się pracy wydawniczej. Będąc zafascynowanym tymi zmianami, wyraził chęć wzięcia udziału w budowaniu nowego życia, w procesie „białorutenizacji”, udzielenia pomocy w organizacji BTN-2 w Witebsku. W tym celu dość szybko podjął decyzję zmiany obywatelstwa: z polskiego na białoruskie. Kończy tę część refleksja autora o tym, dlaczego przytoczone przez niego fakty zostały pominięte w polskiej wersji książki:

Po tym, jak ukazała się polska wersja wspomnień pt. 7 lat w szponach $G P U$, pytano mnie, dlaczego nic nie piszę o tym, jakie wydarzenia poprzedzały mój areszt i dlaczego nie podałem jego przyczyn. Sprawy te przemilczałem wtedy rozmyślnie: po prostu był mi wstyd. Wstyd mi było, że ja, człowiek dojrzały, dałem się tak naiwnie, tak głupio, tak sromotnie głupio nabrać. [...] Wówczas tak ślepo wierzyłem w radziecką fatamorganę, że nawet agentów Głównego Urzędu Politycznego (GPU) traktowałem jako ludzi godnych zaufania, dżentelmenów, nieomal przyjaciół... Otrzeźwienie przyszło zbyt późno... (s. 10)

W drugiej części pt. Mińsk Alachnowicz dokonał nieznacznych zmian: połączył dwa pierwsze rozdziały (Cela w piwnicy, Mój towarzysz) w jeden ( $W$ piwnicy), ale dodał nowy - pt. Pierwsze przestuchania (Першыля доnьıты). W tym ostatnim zaznaczył, że poinformowano go, że został oskarżony o działalność kontrrewolucyjną („udzielenie pomocy międzynarodowej burżuazji") na podstawie 58 artykułu kodeksu karnego i został skazany na dziesięć lat łagru. Jak podkreśla Alachnowicz, uświadomił sobie wtedy, że wszystko, co działo się z nim w ostatnim czasie - zachęcenie do wyjazdu na Białoruś, propozycja objęcia posady kierownika literackiego w nowo 
powstałym BTN-2, nakłanianie do zmiany obywatelstwa było prowokacją. Głównym celem władz białoruskich był areszt. Cztery inne części książki pozostały bez zmian.

\section{Wydanie w języku polskim: „Prawda o Sowietach: wrażenia z 7-letniego pobytu w więzieniach sowieckich r. 1927-1933" (1937)}

W tym samym roku Alachnowicz wydał także polską wersję powieści, ale pod innym tytułem. Prawdopodobnie był to chwyt marketingowy, aby książka mogła się pojawić w stolicy i dotrzeć do większej liczby odbiorców. Wątpliwe, aby w rachubę wchodziło honorarium, ponieważ na okładce zaznaczono: „Nakładem autora”.

Powieść miała taką samą kompozycję, jak wydanie białoruskie tegoż roku. Zostały poszerzone poszczególne rozdziały. Wykonane przez Alachnowicza tłumaczenie różniło się od białoruskiej wersji: autor wprowadzał nieco inne konstrukcje i uzupełniał tekst, dodając drobne szczegóły. Na okładce została narysowana gwiazda oraz czaszka człowieka jako ofiary socjalizmu. Ponadto publikacja zawierała zdjęcia, przedstawiające życie codzienne ówczesnego ZSRR: handel na ulicach Mińska; bazar w Leningradzie; ogromne kolejki przed sklepem spożywczym; ziemianki, zamieszkałe przez biedne rodziny; tramwaj w Moskwie, przepełniony pasażerami; kobieta listonoszka z Irkucku; dzieci, poszukujące jedzenie w śmietnikach; siedząca na ulicy sierota i prosząca o jałmużnę; żebrak uliczny, który przeszedł prawie przez całą Rosję; ofiary panującego na Ukrainie głodu; stosy trupów, czekających na pochówek; zburzone cerkwie.

\section{Wydanie w języku białoruskim: „У капцюрох ГПУ” (1942)}

Praca nad powieścią trwała dalej i została ukończona w 1942 roku. Świadczy o tym informacja podana na końcu: „Wilno 1942”. Przygotowując ją do druku, Alachnowicz czynił wszystko, aby dokładnie opisać okres przygotowania do wyjazdu na Białoruś oraz pobyt w Mińsku i Witebsku. Tak o tym wspomina sam autor: Trzeba było napisać o tym, co sie wydarzyło między 17 listopada 1926 roku a 1 stycznia 1927 roku. Bez tego wiele było niejasności. Jedni pytali: „Za co, koniec końców, bolszewicy posadzili tego Alachnowicza?”. A inni zaś mówili: „E, musiało coś być! To nie jest przypadek... Tak za nic cztowieka do więzienia nie wsadza...” (s. 258-259). 
Dodane fakty pochodzą z rozmów pisarza z matką, żoną i przyjaciółmi. Także wykorzystano materiały z prasy tych lat. W ten sposób historia stała się pełna, uzyskała większą rangę i znaczenie.

W tym celu autor wprowadził dwie nowe części (część I - Biльня (Wilno), część II - Менск (Minssk), rozszerzył część IV pod tytułem Mińsk i dodał epilog. Część pod tytułem Mińsk już istniała w powieści (był w niej opisany okres aresztu), ale teraz autor chciał skupić się na pierwszym etapie swojego pobytu na Białorusi, mianowicie po przyjeździe do Mińska z Wilna. Z kolei część IV pod tym samym tytułem, która była w powieści od samego początku, teraz została znacznie rozszerzona o siedemnaście rozdziałów, a jeden rozdział, Moü mаварьиш (Mój towarzysz), został uzupełniony o nowe informacje. O cztery nowe rozdziały uzupełniono część pt. Sołowki.

W rezultacie powieść zyskała następującą kompozycję:

Część I - Wilno - zawiera sześć rozdziałów: Ax, як maм добра... (Ach, jakże tam dobrze...), Госць з Менску (Gоść z Mińska), У "Беларускай Радзе” (W „Radzie Biatoruskiej”), Папутчык у сваёй хаче (Poputczyk w swoim doти), Падрыхтоўка да падарожжа (Przygotowania do podróży) oraz Bыезд (Wyjazd).

Część II - Minssk - zawiera trzynaście rozdziałów: $У$ заезджbıм доме ( $W$ zajeździe), Y тэатры ( $W$ teatrze), Тэатр у Вічебску (Teatr w Witebsku), Першая льюка дзёгцю (Pierwsza tyżka dziegciu), Гутарка суседак (Rozmowa sasiadek), ГРУ настройвае (GPU nakierowuje), Неспадзявань госиь (Nieoczekiwany gość), Першы раз у ГПУ (Po raz pierwszy w GPU), Перад арэапагам (Przed areopagiem), “Товарищеская чашка чаю” ( „Коleżeńska filiżanka herbaty”), Таварышы “работают” (Towarzysze „pracuja”), У апартаментах дыпламата (W apartamentach dyplomaty), Новы савецкі грамадзянін (Nowy radziecki obywatel).

Część III - Witebsk - została nieco zmieniona, ale zawarta w niej informacja pozostała bez zmian. W nowej wersji też ma trzy rozdziały: Пeрад Новым годам ( $W$ przeddzień sylwestra), Філёр (Filer), Без маскі (Bеz maski).

Część IV - Mińsk - ma siedemnaście nowych rozdziałów: Ha dpyai дзень (Na drugi dzień), Першыл допьты (Pierwsze przestuchania), Адна надзея адпала (Jedna nadzieja odpadta), Матчьна роспач (Rоzрасz matki), Апошняя надзея развеялася (Zniknęła ostatnia nadzieja), Жонка збіраеица ў дарогу (Żona wybiera sie w droge), Другія допьтыь (Kolejnе przestuchania), Новыя допыты (Nowe przestuchania), Цяжкія часіньь (Trudne czasy), Прысуд (Wyrok), Допр (Dopr), Лiст да прыляелячу (List do przyjaciót), Апошняе развітанне (Ostatnie pożegnanie), У Воршыл (W Orszy), Вічебск (Witebsk), У кабінеце Прэзідента Рэспублікі 
(W gabinecie Prezydenta Republiki), Лicmbы ад прылчеля (Listy od przyjaciela).

Część V - Wyspa Popowska, część VI - Wyspa Miah - zostały bez zmian.

Część VII - Sołowki - uzupełniona o cztery rozdziały: Сенсачblüная нататка (Sensacyjna notatka), Прьияелі (Przyjaciele), Як я зрабіўся загадчыкам IЗО (Jak zostałem kierownikiem działu sztuki), Чac лячеў (Czas leciat).

Część VIII - Kiem - uzupełniona o jeden rozdział: На гітары граю (Gram na gitarze).

Część IX - Moskwa.

Epilog.

Jak już wspomnieliśmy, w białoruskiej wersji z 1937 Alachnowicz wprowadził postać Poputczyka. W najnowszej wersji postać ta występuje aż w czterech częściach. Nie mniej jednak czytelnik od razu rozpoznaje w nim autora publikacji. Jak się wydaje, autor uczynił to z kilku powodów: po pierwsze, by nadać historii nieco uniwersalny charakter i zasugerować, że to mogło się przydarzyć każdemu ${ }^{43}$ (tym bardziej, że w opowieści są pewne przykłady); po drugie, by samemu zdystansować się od wydarzeń, które miały miejsce niezbyt dawno, popatrzeć na nie z pewnej perspektywy. Dlatego ważne miejsce w powieści zajmuje narrator - doświadczony, mądry, wszystkowiedzący. Dość często odwołuje się do faktów, których Poputczyk nie zna. Oto tylko jeden z przykładów. Będąc na bankiecie z pracownikami GPU i wznosząc toast na część radzieckiej Białorusi narrator zaznacza: Poputczyk (zreszta nie tylko on, ale nikt z Białorusinów) nie wiedziat, że dni tej teraźniejszości, która tak się zachwyca, sa już policzone, a wszystkie te „osiagnięcia”, cała białorutenizacja sa krótkotrwałe. Uptynie trochę czasu $i$ zmieni sie kierunek. Rozpoczna sie „nacdemowskie” procesy. Osoby zajmujace wysokie stanowiska będa kończyć życie samobójstwem albo zostana rozstrzelane przez GPU (s. 248).

W pierwszej części Alachnowicz zwrócił uwagę na fakty, które w znacznym stopniu wpłynęły na jego decyzję wyjazdu na Białoruś. Przytoczył między innymi dwie rozmowy, które miały miejsce latem 1926 roku: jedna - z posłem do sejmu polskiego, Białorusinem Piotrem Miatłą ${ }^{44}$, druga zaś

43 Stownik wyrazów obcych $i$ zwrotów obcojęzycznych W. Kopalińskiego podaje: „Poputczyk: towarzysz podróży [...] okolicznościowy, przygodny sprzymierzeniec" (Warszawa 1994, s. 403.)

44 Piotr Miatła (1890-1936) - białoruski publicysta i działaccz narodowy, poseł na Sejm I kadencji w II Rzeczypospolitej Polskiej. 16 I 1927 został aresztowany i skazany na 12 lat więzienia. W 1930 został wypuszczony na wolność w wyniku wymiany więźniów politycznych z BSRR. Został aresztowany (1 IX 1933) i skazany na karę śmierci, zamieniona na 10 lat łagru. Zmarł przy budowie Kanału Białomorskiego. 
z białoruskim działaczem kulturalnym Wiaczasławem Selachem ${ }^{45}$ z Mińska. Miatła w składzie polskiej delegacji odwiedził Mińsk i zachwycał się zmianami, które tam zaszły: powstały białoruskie szkoły, utworzono uniwersytet, zjawiło się sporo utalentowanych pisarzy, nakłady książek sięają kilkudziesięciu tysięcy, w teatrze gra się nowe białoruskie sztuki. Podsumowując stwierdził, że jest tam „ogromne pole do pracy”, a władza białoruska z niecierpliwością czeka na takie osoby, jak Alachnowicz: „Na miejscu pana ani chwili bym się nie wahał" 46 (s. 225). Z kolei Selach stwierdził, że mińscy przyjaciele Alachnowicza „często go wspominają, pragną razem z nim współpracować" (s. 227) i radzą, aby jak najszybciej przeniósł się do Mińska. Wspólna kolacja w restauracji oraz szczera rozmowa tak mocno wpłynęły na autora wspomnień, że zaczął on „na serio marzyć o budownictwie socjalizmu, o radosnym życiu wszystkich robotników w swojej ojczyźnie. Właśnie wtedy podjął ostateczną decyzję o wyjeździe do BSRR" (s. 228).

Aby to zrealizować, należało przekonać rodzinę. W tym celu bohater postanowił wykorzystać autorytet przyjaciela - białoruskiego działacza politycznego i społecznego Szymona Raka-Michajłowskiego ${ }^{47}$, który miał wpływ na jego żonę. W rezultacie nie tylko wyraziła ona zgodę na wyjazd męża na Białoruś podczas urlopu, lecz była gotowa wyjechać tam wraz z dwójką dzieci w przypadku, gdy mąż podejmie decyzję pozostania na Białorusi na zawsze. Po dwóch tygodniach Poputczyk otrzymuje zagraniczny paszport, a następnie radziecką wizę. Pragnienie wyjazdu była tak wielkie, że pewnego razu zamiast bajki opowiada synowi o Białorusi, o „błogosławionym, wolnym kraju oraz o panującej w nim sprawiedliwości, o kraju, w którym człowiek może zrealizować swoje możliwości" (s. 229): Poputczyk nie mógt się doczekać chwili, kiedy będzie mógt wyjechać. Nie byt w stanie na niczym sie skupić. Marzył tylko o Mińsku. Widziat to miasto nawet we

45 Wiaczasłau Selach (wł. Selach-Kaczański, 1885-1976) - działacz teatralny i solista opery. Kierownik sekcji muzycznej Instytuta Kultury Białoruskiej (1924-1928). W latach 1927-1930 dyrektor Białoruskiego Teatru Narodowego-1. Podczas II wojny światowej dyrektor i kieronwik astystyczny Teatru Miejskiego w Mińsku. Od 1944 roku na emigracji, najpierw w Niemczech, a potem w Stanach Zjednoczonych.

46 Ф. Аляхновіч, У капцюрох ГПУ, [w:] Ф. Аляхновіч, Выбраныля творы, Мінск 2005 , с. 223-390. Wszystkie przytoczone w tekście cytaty zostały przetłumaczone przez autora publikacji.

47 Szymon Rak-Michajłowski (1885-1938) - działacz polityczny i społeczny narodowości białoruskiej, publicysta i pedagog; działacz polityczny Białoruskiej Republiki Ludowej (BRL), członek Rady BRL, działacz białoruskiej mniejszości narodowej w II Rzeczypospolitej, w latach 1922-1927 poseł na Sejm Rzeczypospolitej Polskiej I kadencji, od 1926 roku członek Komunistycznej Partii Zachodniej Białorusi. W 1927 roku aresztowany przez władze polskie I skazany na 12 lat więzienia. W 1930 zostaje przedterminowo zwolniony i przyjeżdża do Białoruskiej SRR, gdzie zajmuje szereg stanowisk państwowych. Skazany na obóz pracy, a następnie rozstrzelany z polecenia władz radzieckich. 
śnie. Wydawało mu się, że spaceruje ulicami miasta. Ale podczas snu miat inne uczucie. Odczuwat niepokój i strach. Strach przed nieznanym, strasznym i nieoczekiwanym. Znajomi uciekali przed nim, a on gonit za nimi $i$ nie mógt ich dogonić (s. 230-231).

W dniu 16 listopada bohater wreszcie wsiada do pociągu, który wiezie go do rodzinnego miasta - Mińska. Jak sam twierdzi, nie wiedział, czy spędzi tam tylko urlop - cztery tygodnie, czy podejmie decyzje o pozostaniu na zawsze: To sie później okaże. [...] Na razie Poputczyk marzy o nowym życiu, o nowej pracy, która na niego czeka. I to nie byle jakiej, lecz radosnej i twórczej... (s. 231).

Kolejne rozdziały pierwszej części zostały poświęcone pobytowi bohatera na Białorusi. Już następnego dnia po przybyciu wyruszył on do teatru (od września 1920 roku - Białoruski Teatr Narodowy-148), w którym kiedyś pracował i grał jako aktor. Wszyscy tak się ucieszyli na jego widok, że przerwali próbę, wciągnęli go na scenę i zaczęli go podrzucać. Każdy chciał się z nim przywitać, zadać sporo pytań. Takie przyjęcie mocno wpłynęło na Poputczyka: podobało mu się, że w Mińsku pamięta się o jego zasługach dla teatru białoruskiego. Przez kilka wieczorów gość miał możliwość obejrzenia cieszaccych się popularnością spektakli z repertuaru tego zespołu. Zachwyciła go praca reżysera - Jewstignieja Mirowicza ${ }^{49}$ oraz aktorów. Jednak nie wszystko przypadło mu do gustu, m.in. to, że w sztuce o tematyce historycznej (Kastuś Kalinowski) bohaterowie mówili jako radzieccy komsomolcy, a bohater jednej z inscenizacji (Kariera towarzysza Bryzgalina) za dość niewinne grzechy przeszłości został skazany na śmierć. Kiedy gość wypowiadał swoje uwagi, aktorzy uśmiechali się i mówili: Jesteś tu nowym człowiekiem, niczego nie rozumiesz... Tak trzeba... (s. 235).

Kolejny ważny punkt pobytu Alachnowicza na Białorusi - wyjazd do Witebska, na otwarcie Białoruskiego Teatru Narodowego-2. Po obejrzeniu spektaklu Sen nocy letniej (prem. 22 XI 1926) był zachwycony. Spodobało mu się, że został wybrany utwór nie mający nic wspólnego z tendencyjną bolszewicką literaturą. Ucieszyło go, że grający w tej inscenizacji aktorzy dawno temu stawiali pierwsze kroki na scenie pod jego kierownictwem w „Białoruskiej Chatce” 50 .

\footnotetext{
48 Zob. A. Moskwin, Teatr białoruski: 1920-1930. Odrodzenie i zagłada, Warszawa 2013, s. $31-128$.

49 Jewstigniej Mirowicz (wł. Dunajew, 1878-1952) - aktor, reżyser i dramaturg. W latach 1921-1931 kierownik artystyczny Białoruskiego Teatru Narodowego-1. Jeden z założycieli i kierowników (1945-1952) Białoruskiej Akademii Teatralno-Artystycznej w Mińsku.

50 Białoruska Chatka - klub białoruskiej inteligencji artystycznej, który w latach 1916-1920 prowadził działaność kulturalno-oświatową. W Białoruskiej chatce działała trupa teatralna pod kierownictwem F. Alachnowicza.
} 
Jednak wraz z chwilami radości Alachnowicz doznał rozczarowania. Najpierw odmówiono mu zabrania głosu na uroczystym posiedzeniu z okazji otwarcia teatru, a następnie nie pozwolono wypowiedzieć mu kilku słów na bankiecie. Dyrektor teatru, Mikałaj Krasinski, tłumaczył to w następujący sposób: Pan przyjechał z Zachodniej Białorusi. A głos zabieraja wyłacznie tutejsi. Nie wypada panu przemawiać. Będzie pewien dysonans... (s. 236).

Na bankiecie, jak podkreśla Poputczyk, nikt nie zwracał na niego uwagi. $\mathrm{W}$ rezultacie miał on poczucie, że jest odizolowany od całego teatralnego środowiska. Po powrocie do Mińska próbował pogodzić się z zaistniałą sytuacją i nastroić się na lepsze. Marzył o tym, że otrzyma pozwolenie na stały pobyt i wynajmie skromny domek z ogródkiem na obrzeżach Mińska, gdzie zamieszka z rodziną i matką.

Jednak z czasem bohater doznaje kolejnych rozczarowań. Nie może pojąć, dlaczego aktorzy BTN-1 obawiają się wieczorem wychodzić na kolację do restauracji, lecz wolą „spokojnie rozmawiać” w domu. Zauważa, że niektóre, dobrze znane mu osoby unikają go, starają się jak najszybciej skończyć z nim rozmowę albo zobaczywszy go, przechodzą na drugą stronę ulicy. Ponadto od pewnego czasu zostaje poddany ciągłej obserwacji nieznanych mu osób. Jedni pełnią dyżur w okolicach domu matki, w którym zamieszkał, inni zaś chodzą za nim po mieście.

Kolejny ważny epizod pobytu Poputczyka w Mińsku - kontakty z GPU. Miały one decydujące znaczenie na dalszy los pisarza. Kiedy po raz pierwszy zostaje wezwany do GPU, przeżywa prawdziwy szok: Poputczyk nagle odczut, że stracit wewnętrzna równowage, nogi odmówity mu postuszeństwa, zaczą odczuwać ścisk w gardle, a jedna szczęka nerwowo ocierała o druga. [...] Całe ciato zastabto - przypominat osobe po cięzkiej chorobie. Zaczęto kręcić mu się $w$ głowie. Nie potrafit sie na niczym skupić, w głowie krażyły mu pojedyncze strzępki myśli, jakieś niezwiazane ze soba wyrazy... (s. 239-240).

Oczekując na spotkanie zastanawia się: co mogą uczynić w stosunku do niego? Jak będą się zachowywać? Co mu powiedzą? Czy aresztują? Myśl o areszcie będzie prześladować Poputczyka przez kilka dni. Podczas spotkania z grupą pracowników GPU na czele z zastępcą przewodniczącym mińskiego oddziału GPU J. Opańskim zostaje zapytany o wrażenia z pobytu na Białorusi, o relacje z Tymczasową Radą Białoruskąa1 i Białoruską Włościańsko-Robotniczą Hromadą ${ }^{52}$. Członkowie komisji są ironiczni

51 Tymczasowa Rada Białoruska - polityczna organizacja działająca w Polsce w latach 1924-1926 (Wilno).

52 Białoruska Włościańsko-Robotnicza Hromada (BWRH) - białoruskie lewicowe ugru- 
i zjadliwi w stosunku do gościa: Poputczyk poczuł się źle. Uświadomit sobie, $\dot{z} e$ nikt $z$ obecnych nie wierzy $w$ żadne z jego słów, w jego lojalność, w jego zachwyt nad budownictwem socjalizmu (s. 243). Jednak po chwili wszystko się nagle zmienia, a ironię i szyderstwo zastępuje życzliwość. Zaproszono go nawet na imprezę, która miała się odbyć następnego dnia. Poputczyk przeżył kolejny szok: $W$ jego umyśle zapanował chaos... Poczuł się zbity z tropu, a w głowie klębity się sprzeczne pytania, na które nie potrafit znaleźć odpowiedzi... (s. 244).

Po kilku dniach Poputczyk zostaje ponownie wezwany do GPU i poinformowany o tym, że w wileńskiej gazecie ukazał się artykuł, kompromitujący go. Po powrocie może zostać aresztowany i skazany na wiele lat więzienia. Zaproponowano mu rezygnację z polskiego obywatelstwa i przyjęcie radzieckiego. Gość ani chwili się nie waha i zgadza się. A już po dziesięciu dniach zostaje obywatelem ZSRR.

Na bankiecie, który odbywa się na cześć Poputczyka w skromnym mieszaniu jednego z pracowników GPU, przeżywa strach bycia otrutym. Jednak po długiej walce ze sobą usiłuje dostosować się do niezwykłej dla niego sytuacji: dużo opowiada o swojej rodzinie, o „nieznośnych” warunkach życia w kapitalistycznym państwie, o pragnieniu pozostania na Białorusi i włączenia się $\mathrm{w}$ proces budowania socjalizmu. Po kilku wypitych kieliszkach postanawia nawet zabrać głos:

Towarzysze! Następnego dnia po przybyciu do Mińska wyjrzałem z okna i zobaczyłem cegłę. [...] To bardzo symboliczne! To coś wyjątkowego! Cegła to budowniczy materiał, z cegły buduje się nowe domy. W tej chwili, jak nigdy wcześniej, uświadomiłem sobie, dokąd przyjechałem. Przybyłem do kraju Wielkiego Budownictwa! Do kraju, w którym odbywa się proces niszczenia starych form życia w celu zbudowania nowego systemu, opartego na sprawiedliwości, w którym nie ma wyzysku ludzi pracy... Towarzysze! Wznoszę ten toast za budownictwo socjalizmu! (s. 247)

Kiedy Poputczykowi się wydaje, że nastąpił kres jego przeżyciom i stra$\mathrm{chu}$, filery ponownie nie pozostawiają go w spokoju, Wtedy podejmuje on decyzję zasięgnięcia rady u znajomych mu osób - najpierw u przewodniczącego Instytutu Kultury Białoruskiej Usiewałada Ihnatowskiego ${ }^{53}$, a następ-

powanie polityczne w okresie międzywojennym, utworzone w 1925 roku. Wydawała ona kilka pism, a jej liczebność osiągnęła ok. 120 tys. członków.

53 Usiewaład Ihnatouski (1881-1931) - białoruski działacz narodowy, komisarz oświaty BSRR, dyrektor Instytutu Kultury Białoruskiej (1926-1929) i pierwszy przewodniczący Akademii Nauk BSRR (1928-1931). 
nie radcy ambasadora ZSRR w Polsce Aleksandra Uljanowa ${ }^{54}$, z którym kiedyś miał okazję rozmawiać. Obiecują oni pomóc w trudnej dla niego sytuacji, ale, jak sugeruje narrator, nic dla tego nie czynią. W rezultacie Poputczyk zostaje aresztowany.

Do części IV, tuż po areszcie, Alachnowicz wprowadził wiele istotnych faktów i refleksji. Przecież jak większość osób, niewinnie aresztowanych, jego bohater, Poputczyk, wierzył w to, że wcześniej czy później zostanie wypuszczony na wolność. Autor opowiedział czytelnikowi o tym, jak odebrał areszt, co przeżywał podczas aresztowania, szczególnie w ciągu pierwszych tygodni. Na przykład, w podrozdziale $N a$ drugi dzień Alachnowicz opisał swoje pierwsze, zresztą bardzo krótkie spotkanie z pracownikiem GPU. Za wszelką cenę pragnął się dowiedzieć, dlaczego został aresztowany. Usłyszał, że jest to kara za „wcześniejsze grzechy” (s. 262). W Moim towarzyszu przytoczył on rozmowę z Łotewskim oficerem, podczas której nie bał się opowiedzieć mu o swojej sprawie, m.in. o przyjeździe do ZSRR, o wezwaniu do GPU i przeprowadzonych rozmowach. Kiedy zapytał go, co ten myśli o jego losie, usłyszał: Minimalnie może pan otrzymać pieć lat $i$ zostanie pan zesłany do Wschodniej Syberii albo na Wyspy Sołowieckie... Mniej nie dadza. [...] Ale większość osób otrzymała dziesięć lat albo została rozstrzelana (s. 264).

Słowa te bardzo przestraszyły Poputczyka. By nieco się uspokoić, zaczął myśleć o tym, że jego przyjaciele, członkowie Hromady, uratują go: Powinni się o mnie dowiedzieć! Przecież nic jeszcze nie wiedza, ale z czasem na pewno sie dowiedza i wtedy będe wolny. Otworza się drzwi więzienia - i kto wie, być może GPU będzie mnie przepraszać za „popetnione niedogodności” (s. 264).

Gdy po raz pierwszy został wezwany na przesłuchanie, szedł na nie z przekonaniem, że wreszcie będzie miał możliwość szczerze porozmawiać: Powiem wszystko. Przecież nie mam czego ukrywać. No i oczywiście, jak tylko mnie wystuchaja, natychmiast zwolnia. A jeśli nawet nie od razu, to następnego dnia, albo za kilka dni - po załatwieniu wszystkich formalność (s. 266).

Gdy pracownik GPU kazał Poputczykowi opowiedzieć o działalności Tymczasowej Rady Białoruskiej, ten zaczął snuć opowieść o swoim przyjeździe na Białoruś, pragnieniu włączenia się w proces kulturalnego budownictwa. Potem zwrócił się z prośbą o napisanie listu do matki. Na zakończenie spotkania oficer kazał podpisać dokument, w którym Poputczyk przyzna-

\footnotetext{
54 Aleksandr Uljanow (1901-1937) - polityk i dyplomata. W latach 1922-1924 zastępca przedstawiciela Ludowego Komisariatu Handlu Zewnętrznego Federacji Rosyjskiej w BSRR, w latach 1925-1928 - radca ambasadora ZSRR w Polsce. W 1937 roku aresztowany.
} 
wał się do „udziału w kontrrewolucyjnej organizacji, mającej na celu walkę z robotniczym ruchem na Zachodniej Białorusi" (s. 268) oraz do współpracy z polską defensywą. Ten nie tylko nie zgodził się, lecz zareagował dość ostro: Pan i pańscy koledzy sa chorzy. Każda osobe traktujecie wyłacznie jako wroga radzieckiego systemu. Prawdopodobnie jest to skutkiem zawodowej choroby (s. 269). Te ostatnie słowa na tyle rozzłościły oficera, że natychmiast przerwał spotkanie: Wystarczy! Innym razem porozmawiamy (s. 269).

Po powrocie do celi Poputczyk nie mógł dojść do siebie i uwierzyć w to, że właśnie tak potoczy się rozmowa. Miał tylko jedną radość z tego, że mógł napisać list do matki. Był przekonany, że przekaże ona informacje o jego areszcie członkom Hromady i dość szybko zostanie zwolniony. Jednak spadły na niego dwa nowe ciosy: w rozmowie z innym więźniem dowiedział się, że na podstawie kodeksu cywilnego grozi mu rozstrzelanie albo trzy lata więzienia, a po przeczytaniu ostatniego numeru dziennika „Савецкая Беларусь" Poputczyk dowiedział się, że członkowie partii, której był członkiem i na pomoc której bardzo liczył, zostali aresztowani. Mimo to dalej naiwnie wierzył, że jednak ktoś może mu pomóc, m.in. wspomniany wcześniej A. Uljanow. Jednak nadzieja w stosunku do tej osoby wkrótce rozwiała się. Wynikło to podczas spotkania z matką. Opowiedziała synowi, że po otrzymaniu listu z więzienia wpadła w rozpacz, ale odważyła się pójść na rozmowę z dyplomatą i poprosić go o pomoc. Ten odparł: Niech sobie posiedzi. To potrwa dtugo. Więcej nie będzie chciat bawić się w kontrrewolucję (s. 272).

Matka Popytczyka była jedyną osoba, która za wszelką cenę usiłowała pomóc mu, starała się wyzwolić go z więzienia ${ }^{55}$. Odwiedzając go, przynosiła mu ulubione pierożki z grzybami i papierosy. Starała się także przekazać poduszkę i koc. Ponadto poinformowała o jego losie małżonkę. Na przykład, z rozdziału Żona zbiera się $w$ droge dowiadujemy się, że wysprzedała ona w Wilnie prawie cały majątek, zostawiając tylko łóżko, parę krzeseł oraz stolik. Przebywając z dwojgiem dzieci w pustym nieprzytulnym mieszkaniu czekała na list od małżonka. Z powodu braku pieniędzy nie była $\mathrm{w}$ stanie opłacić rachunków za elektryczność i kupić węgiel. Wieczorem zapalała świeczkę i paliła piec drewnem. Przyjaciele męża dokładają staran, aby ją uspokoić. Twierdzą, że prawdopodobnie ma problemy z załatwieniem formalności, że nie otrzymał jeszcze pieniędzy, że po pewnym czasie wróci i zabierze rodzinę na Białoruś.

55 Matka F. Alachnowicz wystosowała list do Centralnego Komitetu Wykonawczego BSRR, w którym m.in. pisała: „Bardzo proszę go uniewinnić, dać mu możliwość pracować na rzecz ZSRR i złagodzić warunki jego życia, aby miał on możliwość całkowicie poświęcić się proletariackiej twórczości dramaturgicznej". (М. Олехнович, В ЦИК БССР, [w:] Ф. Аляхновіч, Выбраныяя творыл, Мінск 2005, с. 511-512). 
Dopiero list od matki tłumaczy całą sytuację Poputczyka. Po przeczytaniu informacji, że syn ciężko zachorowat, le ży w szpitalu i nie wiadomo, kiedy wyzdrowieje. Nadziei na szybkie poprawienie stanu zdrowia raczej nie ma (s. 274), była zszokowana. Kilka razy czytała ten list i nie była w stanie zrozumieć jego sensu: przecież od dłuższego czasu mąż nie skarżył się na chorobę i zawsze wykazywał się dobrym samopoczuciem. Dopiero po dokładnym przeanalizowaniu słów uświadomiła sobie, że małżonek został aresztowany. W dodatku jej sytuacja stała się trudna po tym, jak w wileńskiej prasie ukazała się informacja, że Poputczyk jest agentem Sowietów.

Niedługo przed ogłoszeniem wyroku Popytczyka ogarnął strach, że nigdy nie wyjdzie żywym z więzienia: Pragnałem zajrzeć do swojej przyszłości. Jednak zapytać się: „Czy zostane rozstrzelany?” nie mogłem, ponieważ to oznaczałoby, że takie rozwiazanie jest możliwe $i w$ ten sposób uważam siebie za przestępce, który zastużyt na taka właśnie kare (s. 282).

Podczas kolejnego przesłuchania, kiedy został oskarżony o terroryzm, już nie miał wątpliwości, że zostanie stracony. Po powrocie do celi wyobrażał sobie, w jaki sposób to się odbędzie ( „zwiaża ręce”, „będa prowadzič”, „rzuca na podtogę", s. 278-288) i jakie będą go ostatnie myśli.

W rozdziałach List do przyjaciót i Listy od przyjaciela Alachnowicz opowiada o korespondencji z dwoma literatami (niestety, autor nie wymienia nazwisk tych dwóch osób), którzy próbowali mu pomóc. W wysłanych do Poputczyka listach jeden z nich informował, że w jego sprawie wystosowali oni odpowiednie podania do różnych urzędników, w tym do przewodniczącego GPU ZSRR Wiaczesława Mienżyńskiego ${ }^{56}$. Między innymi pisał: Proszę nie poddawać sie rozpaczy. [...] Mamy nadzieję, że sprawa zostanie pozytywnie rozpatrzona. Trzeba mieć cierpliwość i nie tracić wiary... (s. 296). Jednak z każdym kolejnym listem nadzieja malała. Natomiast w rozdziale $W$ gabinecie Prezydenta Republiki jest mowa o rozmowie literatów z przewodniczącym Prezydium Centralnego Komitetu Wykonawczego BSRR Alaksandrem Czarwiakowem ${ }^{57}$. Ale i on niezbyt entuzjastyczne podszedł do sprawy: Szczerze mówiac, czy warto podejmować jakieś kroki? Zbliża się dziesiata rocznica rewolucji $i$ odbędzie sie amnestia. Wtedy $i$ on [Alachnowicz] zostanie zwolniony, i nie będzie potrzebny nasz wysitek (s. 295).

56 Wiaczesław Mienżyński (1874-1934) - funkcjonariusz sowieckiej policji politycznej i bezpieczeństwa. W latach 1926-1934 szef Zjednoczonego Państwowego Zarządu Politycznego GPU. Często chorował i prawdopodobnie zmarł na atak serca.

57 Alaksandr Czarwiakou (1892-1937) - białoruski polityk i działacz narodowy. Premier Białorusi w latach 1920-1924, głowa państwa (1920-1937) i sekretarz partii komunistycznej. 
Jak wynika z opowiadania, wysiłek białoruskich przyjaciół i kolegów58 Alachnowicza poszedł na marne. Natomiast w Polsce pomógł mu Marian Świechowski (rozdział Przyjaciele). Jak pisze autor, chociaż nie zajmowat on żadnego wysokiego stanowiska, ale miat kontakty $i$ byt osoba wptywowa. Osoby, które kierowały państwem, liczyły się z jego zdaniem (s. 364). W rezultacie nazwisko Alachnowicza trafiło do listy osób, które Rzeczpospolita Polska wymieniła z Białorusią.

W Epilogu Alachnowicz wyznaje, że po powrocie do Wilna pojawiła się potrzeba opisania tego, co przeżył na Wyspach Sołowieckich, opowiedzenia o tym ludziom, aby „otworzyły im się oczy”. Zaczął również zastanawiać się nad tym, gdzie opublikować wspomnienia. Najpierw zaproponował białoruskiemu dziennikowi „Крыніца”, ale redaktor odmówił usprawiedliwiając się nawałem materiału. Zgodę wyraził redaktor polskiej gazety „Słowo” Stanisław Mackiewicz („Cat”). Później Alachnowicz przygotował kolejne wersje: rosyjską i ukraińską. Wreszcie jestem na wolności. Ciesze się, jestem pijany od nadmiaru swobody. Nie moge znaleźć sobie miejsca. Ide sobie tam, gdzie mi się chce, przejde sie, spotykam sie z jednym, a potem z drugim. Zawsze mam kogo odwiedzić. I czuje sie jakoś dziwnie: nikt mnie nie obserwuje, nie potrzebuję żadnej przepustki. Ide sobie tam, gdzie mi sie chce (s. 387) - kończy swoją opowieść.

Podsumowując należy stwierdzić, że dokumentalna powieść F. Alachnowicza "7 lat w szponach GPU” rozpoczyna tematykę łagrową w literaturze białoruskiej XX wieku. Pisarz na własnym doświadczeniu pokazał, jak w latach 20. XX wieku wielu osób uwierzyło propagandzie radzieckiej i postanowiło przyjechać na Białoruś, aby włączyć się w proces „białorutenizacji”. Jednak władza radziecka nie chciała skorzystać z ich wiedzy i doświadczeń, uczyniła wszystko, aby zostali oni odizolowani i wysłani do łagru. Po powrocie do Wilna Alachnowicz stworzył przewodnik po życiu łagrowym. Ważne miejsce zajmuje w nim życie codzienne więźniów, metoda pracy pracowników GPU. Niniejsza publikacja jest dowodem na to, że wprowadzony przez

\footnotetext{
58 List do przewodniczącego Rady Komisarzy Ludowych BSRR Mikałaja Haładzieda w obronie Alachnowicza wystosowała grupa białoruskich pisarzy, wśród których byli: Janka Kupała, Jakub Kołas, Zmitrok Biadula i Maksim Harecki. Ten ostatni pisał także do Centralnego Komutetu Wykonawczego BSRR (19 VII 1927). W archiwum pisarza zachował się obszerny dokument w języku rosyjskim, w którym on przytacza szczegółową biografię Alachnowicza. Prawdopodobnie documentę tė̇ był przeznaczony do jednego z urzędów radzieckich. M.in. pisał w nim: „W imię rewolucyjnej sprawiedliwości, w imię honoru człowieka, pisarza i artysty, w imię białoruskiej literatury i teatru, w imię troski o starą matkę i dwójki małych dzieci, uwzględniając jego przeszłe zasługi proszę, aby sprawa ta dokładnie została ponownie zbadana" (М. Горецки й, Франи Калович Олехнович, [w:] Ф. Аляхновіч, Выббраныя творы, Мінск 2005, с. 518).
} 
władzę system wychowania w rzeczywistości staje się narzędziem do gwałtu nad człowiekiem.

\section{I T E R A T UR A}

Alâhnovič F., 7 lit na Solovkah: spomini bilorus'kogo dîăčapro martirologîu u Sovitah, L’vìv 1937 [Аляхновіч Ф., 7 літ на Соловках: спомини білоруського діяча про мартирологію у Совітах, Львів 1937].

Alâhnovič F., U kapcûroh GPU. Drukarnâ I. Baeŭskaga, Vil'nâ 1937 [Аляхновіч Ф., У капцюрох ГПУ. Друкарня I. Баеўскага, Вільня 1937].

Alâhnovič F., U kapcûroh GPU, „Mìnskaâ praŭda” 1941, nr 7-12, 14-17, 19; 1942 - nr 1, 2, 4, 6, 7, 9-12, 14, 15, 17, 18, 21, 22, 24, 25, 29, 31, 32, 36, 37, 39, 41 [Аляхновіч Ф., У капиюрох ГПУ, „Мінская праўда” 1941 - nr 7-12, 14-17, 19; 1942 - nr 1, 2, 4, 6, 7, 9-12, 14, 15, 17, 18, 21, 22, 24, 25, 29, 31, $32,36,37,39,41]$.

Alâhnovič F., U kapcûroh GPU, „Polymâ” 1991, № 1 [Аляхновіч Ф., У капиюрох ГПУ, „Полымя” 1991, № 1].

Alâhnovič F., U kapcûroh GPU, Mìnsk 1994 [Аляхновіч Ф., У капцюрох ГПУ, Мінск 1994].

Alâhnovič F., U kapcûroh GPU, [u:] F. Alâhnovič, Vybranyâ tvory, Mińsk 2005 [Аляхновіч Ф., У капчюрох ГПУ, [у:] Ф. Аляхновіч, Выбраныяя творы, Mińsk 2005].

Alâhnovič F., U kapcûroh GPU, Mìnsk 2015 [Аляхновіч Ф., У капцюрох ГПУ, Мінск 2015].

Bagaradava T., Netradycyjnasc' prablematyki apovesci F. Alâhnovǐca „U kapcûroh GPU”, „Vestnik Polockogo gosudarstvennogo universiteta: naučno-teoretičeskij žurnal", Polock 2016, № 2 [Багарадава Т., Нетрадыиыйнасиь праблематыкі аповесиі Ф. Аляхновіча „У капцюрох ГПУ”, „Вестник Полоцкого государственного университета: научно-теоретический журнал”, Полоцк 2016, № 2].

Bâlâckì A., „Bo lës byŭ naš - muk doŭgì, večny šlâh...”, [u:] F. Alâhnovič, U kapcûroh GPU, Mìnsk 1994 [Бяляцкі А., „Бо лёс бый наш - мук доўгi, вечны шлях...", [у:] Ф. Аляхновіч, У капиюрох ГПУ, Мінск 1994].

Bezsonov Y., Mes vingt-six prisons et mon évasion de Solovki (traduit du E. Semenoff), Paris 1928, 288 pp.

[Danzas I.], Bagne rouge. Souvenirs d'une prisonnière au pays des Soviets. Les Éd. du Cerf - Istina, Centre dominicain d'études russes, Juvizy 1935.

Drozd K., Białoruska proza łagrowa, Warszawa 2016.

Drozd K., „W szponach GPU” - o największym wrogu ludzkości, cz. 1. „Acta Albaruthenica", t. 8 . 
Drozd K., „W szponach GPU” - o największym wrogu ludzkości, cz. 2. „Acta Albaruthenica", t. 9.

Duguet R., Un bagne en Russie rouge, Paris 1927.

Goreckij M., Franc Kalovič Olehnovič, [v:] F. Alâhnovič, Vybranyâ tvory, Mìnsk 2005. [Горецкий М., Франи Калович Олехнович, [в:] Ф. Аляхновіч, Выбраныля творы, Мінск 2005].

Kopaliński W., Stownik wyrazów obcych i zwrotów obcojęzycznych, Warszawa 1994.

Malsagoff Sozerko, An Island Hell: A Soviet Prison in the Far North (translated by Francis Hamilton Lyon), London 1926, 223 pp.

Moskwin A., Teatr białoruski: 1920-1930. Odrodzenie i zagłada, Warszawa 2013.

Olechnowicz F., 7 lat w szponach GPU, Wilno 1935.

Olechnowicz F., 7 lat w szponach GPU, Warszawa 1990.

Olechnowicz F., La Verità sulla Russia Bolscevica. Casa editrice G. Nerbini, Firenze 1938.

Olechnowicz F., Prawda o Sowietach. Wrażenia z 7-letniego pobytu w więzieniach sowieckich r. 1927-1933, Warszawa 1937.

Olechnowicz F., Sete annos nas garras Sovieticas, São Paulo 1937.

Olehnovič M., V CIK BSSR, [w:] F. Alâhnovič, Vybranyâ tvory, Mìnsk 2005 [Олехнович М., В ЦИК БССР, [w:] Ф. Аляхновіч, Выљрраныля творы, Мінск 2005].

Ponarski Z., Franciszek Olechnowicz - wydawca, redactor, publicysta, „Białoruskie Zeszyty Historyczne" 1996, z. 2 (6).

Sakovì A., Pakutnikiza narod i Bac'kaǔščynu. (Memuary Franciška Alâhnoviča i Ânki Žamojcina), [w:] Białoruś: przeszłość i teraźniejszość: kultura, literatura, język, pod red. R. Radzik, M. Sajewicz, Lublin 2010 [Саковіч A., Пакутнікі за народ і Бачькаўшчыну. (Мемуары Франиішка Аляхновіча $і$ Янкі Жамойчіна), [w:] Białoruś: przeszłość i teraźniejszość: kultura, literatura, jezzyk, pod red. R. Radzik, M. Sajewicz, Lublin 2010].

Solonewitsch I., Die Verlorenen. Eine Chronik namenlosen Leidens. Rußland im Zwangsarbeitslager 1933, Essen 1937.

Solonevič I., Rossiâ v konclagere, „Poslednie Novosti” (Pariž) 1935 [Солоневич Иван, Россия в конилагере, „Последние Новости” (Париж) 1935].

Solovki ( $v 7$ častâh), [online], https://www.youtube.com/watch?v=O0UJGJwGX 1E [dostęp: 24 VIII 2019] [Соловки (в 7 частях), [online], https://www.you tube.com/watch?v=O0UJGJwGX1E [dostęp: 24 VIII 2019]].

Tchernavin T., Escape from the Soviets, London 1933.

Tchernavin V., I speak for the silent prisoners of the Soviets, Boston - New York 1935. 
Zmìtrovič A.,U kapcûroh GPU, „Polymâ”1991, № 1 [Змітровіч А., У капцюрох ГПУ, „Полымя" 1991, № 1].

Ždanovič A., Sènsaŭtvaral'nyâ asablivasci „U kapcûroh GPU” F. Alâhnoviča $i$ „Apovesci dlâ sâbe” B. Mikulǐca ŭ kantèksce žanrava-stylëvyh prykmet gètyh tvoraŭ, [u:] Kulâšouskîa čytanni: matèryâly Mižnarodnaj navukova-praktyčnaj kanferèncyì, u 2 č., rèd. L. Kìlevaâ ì ìnš., Č. 1. Magìlëŭ 2010 [Ждановіч А., Сэнсаўтваральныяя асаблівасці „У капиюрох ГПУ” Ф. Аляхновіча $i$ „Аповесиі для сябе” Б. Мікуліча й кантэксче жанрава-стылёвых прыкмет гэтых твораў, [у:] Куляшойскія чытанні: матэрыяль Міжнароднай навукова-практычнай канферэнцыі, у 2 ч., рэд. Л. Кілевая і інш., ч. 1, Магілёў 2010].

\section{S U M M A R Y}

\section{FRANCISZEK ALACHNOWCZ'S OEUVRE AS A TESTIMONY OF THE EPOCH}

"7 Years in the Clutches of the GPU" by Franciszek Alachnowicz is a very important book in Belarusian literature. Using his own experience Alachnowicz showed how the Gulag and the process of humiliating a man functioned. In the article its author demonstrates the way Alachnowicz returned to his text four times and each time he supplemented it by adding new details. The book was published in Polish in 1935 and in 1937, and in Belarusian in 1937 and in 1942.

Key words: Belarus, Belarusian literature, documentary prose, Gulag, the Solovetsky Islands, Franciszek Alachnowicz. 